NBER WORKING PAPER SERIES

\title{
INTERNATIONAL INNOVATION AND DIFFUSION OF AIR POLLUTION CONTROL TECHNOLOGIES: THE EFFECTS OF NOX AND SO2 REGULATION \\ IN THE U.S., JAPAN, AND GERMANY
}

\author{
David Popp \\ Working Paper 10643 \\ http://www.nber.org/papers/w10643 \\ NATIONAL BUREAU OF ECONOMIC RESEARCH \\ 1050 Massachusetts Avenue \\ Cambridge, MA 02138 \\ July 2004
}

The author thanks Neelaskhi Medhi, Miki Ouchi, Jacob Brower and Yonghong Wu for excellent research assistance, and Eric Welch for help obtaining environmental regulation data from Japan. Financial support provided by DOE grant DE-FG02-ER63467. The views expressed herein are those of the author(s) and not necessarily those of the National Bureau of Economic Research.

C2004 by David Popp. All rights reserved. Short sections of text, not to exceed two paragraphs, may be quoted without explicit permission provided that full credit, including $\mathbb{C}$ notice, is given to the source. 
International Innovation and Diffusion of Air Pollution Control Technologies: The Effects of NOX and SO2 Regulation in the U.S., Japan, and Germany

David Popp

NBER Working Paper No. 10643

July 2004

JEL No. O31, O33, Q53, Q55

\section{$\underline{\text { ABSTRACT }}$}

Using patent data from the United States, Japan, and Germany, this paper examines both the innovation and diffusion of air pollution control equipment. Whereas the United States was an early adopter of stringent sulfur dioxide (SO2) standards, both Japan and Germany introduced stringent nitrogen dioxide (NOX) standards much earlier than the US. Nonetheless, in both cases, tightened standards in the U.S. led to more domestic patenting, but not more foreign patenting. Overall, the data suggest that inventors respond to environmental regulatory pressure in their own country, but not to foreign environmental regulations. Moreover, any technology transfer that occurs appears to be indirect. Domestic innovation occurs even for technologies that have already experienced significant innovative activity abroad. Moreover, utilities in countries that adopt regulations later nonetheless purchase pollution abatement equipment from domestic firms. However, patent citation data from the U.S. show that earlier foreign patents are an important building block for NOX pollution control innovations in the U.S., suggesting that American inventors build on technological advances made in countries that adopted stringent regulation earlier.

David Popp

Department of Public Administration

Syracuse University

The Maxwell School

400 Eggers

Syracuse, NY 13244-1090

and NBER

dcpopp@maxwell.syr.edu 
Technological change has the potential to play a key role in limiting the effects of longterm environmental problems such as climate change. As such, environmental economists have increasingly paid attention to the links between environmental policy and technology. These links traditionally come in one of two ways. First, environmental policy may induce new innovations by increasing the potential value of producing environmentally-friendly technology. Second, environmental policy may encourage the diffusion of existing environmentally-friendly technologies. However, few studies of technological change, either in the environmental or broader economics literature, link both aspects of technological change. This paper is the first part of a broader research study designed to fill that gap by looking at international technology transfer of pollution control technologies.

This paper uses patent data to investigate flows of air pollution control technology between the United States, Japan, and Germany. In particular, I examine flows of technologies designed to reduce nitrogen oxide $\left(\mathrm{NO}_{\mathrm{X}}\right)$ and sulfur dioxide $\left(\mathrm{SO}_{2}\right)$ emissions by electric utilities. Most previous empirical studies of innovation and adoption of environmental technologies have focused on a single country, and the majority focus on US data. In general, this is appropriate, as the US traditionally has been among the first countries to enact strong environmental regulation and has also been among the first to develop relevant pollution control technologies. However, this is not true in the case of $\mathrm{NO}_{\mathrm{x}}$. Other nations, particularly Japan and Germany, adopted stringent $\mathrm{NO}_{\mathrm{X}}$ regulations earlier than the US. As a result, these nations also developed $\mathrm{NO}_{\mathrm{X}}$ pollution control equipment faster than the US. A study of the innovation and diffusion of $\mathrm{NO}_{\mathrm{X}}$ technologies in the US thus offers an opportunity to study the international diffusion of environmental technologies. In comparison, the US was an early adopter of strong $\mathrm{SO}_{2}$ regulations. Thus, trends in $\mathrm{SO}_{2}$ patents will serve as a useful control, to check whether 
differences in international patenting of pollution control technologies are truly due to differences in international environmental regulation.

In this paper, I use patent data from each of these three countries to track innovation of $\mathrm{NO}_{\mathrm{X}}$ and $\mathrm{SO}_{2}$ technologies. I use these data to answer two related questions. First, what role does environmental policy play in inducing environmentally-friendly innovation? Do domestic environmental regulations spur innovation by foreign inventors, as well as domestic inventors? Second, using patent citations, I examine the role of international knowledge spillovers, asking what contribution patents from foreign inventors make to innovation by domestic inventors in the US. The results suggest that international transfer of these technologies occurs indirectly via influencing domestic inventors - rather than directly. This finding suggests that for countries adopting environmental regulations similar to those already in place elsewhere, domestic R\&D will be needed before technology transfer can occur.

\section{Motivating Theory/Literature Review}

The goal of this paper is to understand how environmental policies both at home and abroad affect the stock of knowledge available within a country. ${ }^{1}$ As such, it draws from two separate sets of literature. Questions about the direct linkages between environmental policy and innovation within a country have been studied using an induced innovation framework. Similarly, questions about flows of knowledge across countries are addressed by papers looking at knowledge spillovers. Figure 1 illustrates the linkages explored in this paper. Circles illustrate variables exogenous to this study, while boxes represent endogenous variables. Solid lines

\footnotetext{
${ }^{1}$ The concept of a knowledge stock represents the current state of technology available for use by firms. Like a physical capital stock, it is typically modeled as a function of previous knowledge and current R\&D investment. See, for example, Griliches (1995). In recent years, several climate policy models have made use of knowledge stocks to model links between environmental policy and technological change. Examples include Goulder and Schneider (1999), Buonanno et al. (2003), and Popp (2004).
} 
represent links well-established in the literature. Broken lines represent links that are less established, and thus the focus of this study.

Within each country, we expect domestic environmental policy to lead to increases in domestic R\&D focused on environmental technologies. Such predictions come from models of induced innovation (Hicks, 1932; Ahmad, 1966; Kamien and Schwartz, 1968; and Binswanger 1974, 1978a, 1978b), which predict that increased input prices encourage innovation to economize on usage of the more expensive input. In this framework, by increasing the costs of using environmental resources, environmental policies induce $R \& D$ designed to protect the environment. Recently, as measures of innovative activity such as patents have become more readily available, empirical economists have begun to estimate the effects that prices and environmental policies have on environmentally-friendly innovation. Examples include Brunnermeier and Cohen (2003), Popp (2002), Newell, Jaffe, and Stavins (1999), and Jaffe and Palmer (1997).

Because of the wealth of data available, each of these studies focuses on innovation in the United States. US environmental standards are typically among the world's most stringent, making it an appropriate study of the need for innovation to comply with environmental regulations. However, because of their focus on US data, as well as a focus on a broad range of environmental technologies, these papers do not provide insight to the incentives for innovation in countries that are latecomers to environmental regulation. Since US coal-fired power plants faced relatively weak standards for $\mathrm{NO}_{\mathrm{X}}$ emissions until the 1990s, this paper offers a look at innovation on a technology when a country is a latecomer to environmental regulation.

While the above papers establish links between domestic policy and domestic R\&D (as well as the links between foreign environmental policy and foreign environmental $R \& D$ in 
Figure 1), little work has looked at the linkages across countries. That is, what effect, if any, does environmental policy in one country have on environmental $R \& D$ in a second country? The one paper to date that does provide some evidence for this question is Lanjouw and Mody (1996), who use patent data from the US, Japan, Germany, and 14 low-and middle-income countries to examine international trends in patenting for a wide range of environmental technologies. As expected, they find that environmentally-friendly innovation increases as pollution abatement cost expenditures in the country increase. For the developing countries, the majority of these patents come from foreign countries. For the US, Japan, and Germany, the majority of these patents are typically domestic patents. However, this is not always the case. In their data, the majority of vehicle air emissions patents granted in the US in their sample are from foreign nations, even though the US was the first country to adopt strict emissions standards. This suggests that regulations in one country can spur innovation by firms in other nations. By focusing on individual air pollutants, this project offers a more detailed look at international patterns of environmental invention than the work of Lanjouw and Mody. In addition, rather than using the indirect proxy of pollution abatement expenditures as a measure of regulatory stringency, I make use of specific variations in regulations to more carefully identify the effects of changes in specific regulations in each country.

The above research addresses how environmental policy affects innovation in each country. Also important is how the knowledge represented by these innovations flow into a country. This is represented by the knowledge stock in Figure 1. There are two potential avenues by which foreign knowledge can have an influence in the domestic economy. First, foreign inventions may enter the knowledge stock and be adopted directly by domestic firms. The direct line between foreign $\mathrm{R} \& \mathrm{D}$ and the available knowledge in Figure 1 illustrates this 
possibility. If the inventor is not completely compensated for the value of the invention, a "spillover" has occurred, as the domestic firm receives a net benefit, but a direct knowledge transfer does not occur, since the ability of the domestic firm to create its own inventions has not increased (Griliches 1979). Rather, this is a pecuniary externality. Second, foreign knowledge entering the knowledge stock may affect the productivity of domestic R\&D. The "blueprints" represented by foreign patents may serve to inspire additional innovation by domestic inventors. These represent true knowledge spillovers, as the knowledge represented by the foreign patent creates a positive externality - knowledge which is borrowed by the domestic inventor (Griliches 1979). Such spillovers are shown by the line between foreign and domestic R\&D in Figure 1 . In addition, the connection between the knowledge stock and domestic R\&D flows both ways, as technological advances may serve as building blocks for future R\&D.

Note that these two avenues have different implications for the timing of innovation and adoption of new pollution control technologies in countries that are late adopters of environmental regulations (follower countries). In the case of direct adoption, the technology will already exist, having been invented in countries that were early adopters of environmental regulations (leader countries). As such, follower countries should experience rapid adoption of new technologies. ${ }^{2}$ However, direct adoption might not be possible. Domestic R\&D may be needed to make modifications of foreign inventions to make them compatible with local markets. For example, both Cohen and Levinthal (1989) and Griffith, Redding, and Van Reenen (2003) find positive links between R\&D and the ability of firms to absorb knowledge spillovers. Foreign knowledge can still be beneficial in this case, as it provides knowledge on which

\footnotetext{
${ }^{2}$ The beneficiaries of the adoption, however, may be the innovators from leader countries, who experience increased sales due to regulations in the follower country. Such a finding would support the early mover advantage hypothesized by Porter as one reason why environmental regulations may increase international competitiveness (Porter and van der Linde 1995).
} 
domestic inventors can build. This paper uses the timing of patent applications and regulations across countries to identify these effects. If direct adoption is the primary means of technology transfer, most environmental patents in each country should come from the technology leader, and there should not be a corresponding burst of patenting activity in countries that adopt regulations later. In comparison, if additional $\mathrm{R} \& \mathrm{D}$ is needed to adapt innovations, we would expect additional domestic patenting activity as each nation strengthens its own environmental regulations.

In addition, I use patent citations to measure knowledge flows across nations, to ask how important knowledge spillovers from the leader country are to these domestic inventions. When a patent is granted, it contains citations to earlier patents that are related to the current invention. In recent years, several economists have used patent citations as a measure of knowledge flows. ${ }^{3}$ Examples include Jaffe, Fogarty, and Banks (1998), Jaffe and Trajtenberg (1996), Caballero and Jaffe (1993), Jaffe, Henderson, and Trajtenberg (1993), and Johnson and Popp (2003). Most related to this work, Jaffe and Trajtenberg (1999) use data from citations granted in the US to estimate the likelihood of citations across "pairs" of countries. Looking at broad sets of technologies (e.g. all chemical technologies), they find that patents are most likely to cite other patents assigned to inventors from the same country. Looking at more distinctly defined environmental technologies, in this paper, I show that this relationship changes for technologies first developed abroad.

\footnotetext{
${ }^{3}$ Jaffe and Trajtenberg (2002) review this literature.
} 


\section{Regulation of $\mathrm{NO}_{\mathrm{X}}$ and $\mathrm{SO}_{2}{ }^{4}$}

Both $\mathrm{NO}_{\mathrm{X}}$ and $\mathrm{SO}_{2}$ have received significant attention from regulators for over 30 years. $\mathrm{NO}_{\mathrm{X}}$ emissions are produced by the combustion of fossil fuels, when nitrogen contained in the fuel combines with oxygen during the combustion process. $\mathrm{NO}_{\mathrm{X}}$ emissions can be reduced either by making modifications to the combustion process or by using post-combustion control techniques. Major environmental concerns resulting from $\mathrm{NO}_{\mathrm{X}}$ emissions are ground-level ozone and acid rain. $\mathrm{SO}_{2}$ emissions come from burning coal or oil as a fuel. The primary concern form $\mathrm{SO}_{2}$ emissions is acid rain. $\mathrm{SO}_{2}$ emissions can be reduced by switching to cleanerburning coal or using flue gas desulfurization (FGD) units (commonly known as "scrubbers”) to remove emissions. This section reviews the regulation of $\mathrm{NO}_{\mathrm{X}}$ and $\mathrm{SO}_{2}$ in the US, Japan and Germany. Figure 2 summarizes $\mathrm{NO}_{\mathrm{X}}$ regulations in the three countries. $\mathrm{SO}_{2}$ regulations have not varied over time as much, and are simply described in the text below. Regulations are expressed in both the local units used in each country and in $\mathrm{mg} / \mathrm{m}^{3}$, which is the most commonly used unit across countries.

\section{A. United States}

In the United States, $\mathrm{NO}_{\mathrm{X}}$ and $\mathrm{SO}_{2}$ are two of six criteria pollutants regulated by the Clean Air Acts. The first national standards for $\mathrm{NO}_{\mathrm{X}}$ and $\mathrm{SO}_{2}$ were set by the 1970 Clean Air Act (CAA). US $\mathrm{SO}_{2}$ emissions limits have historically been among the most stringent in the world. The 1970 CAA established a limit of 1.2 pounds of $\mathrm{SO}_{2}$ per million Btu (lbs/mmBtu) of heat input for power plants (equivalent to $1480 \mathrm{mg} / \mathrm{m}^{3}$ ). The 1977 CAA kept this limit, but added technology-forcing language that essentially required the use of scrubbers to achieve at

\footnotetext{
${ }^{4}$ Except where otherwise noted, information in this section comes from a series of publications on emission standards published by the International Energy Agency Clean Coal Centre: Vernon (1988), Soud (1991), McConville (1997), and Sloss (2003).
} 
least $90 \% \mathrm{SO}_{2}$ removal. The $1990 \mathrm{CAA}$ established $\mathrm{SO}_{2}$ emission permit trading, in which plants are required to hold permits for each ton of $\mathrm{SO}_{2}$ emitted. The number of permits were restricted, with the goal of reducing emissions to 10 million tons less than 1980 levels by 2000 . As is well documented, the permit trading program has successfully achieved this goal at costs significantly lower than would have been possible without trading (see, for example, Ellerman et al. 1997).

In comparison, $\mathrm{NO}_{\mathrm{X}}$ emissions were primarily seen as a local issue until the 1990 Clean Air Act. $\mathrm{NO}_{\mathrm{X}}$ emissions results in two major environmental problems - the formation of ground-level ozone and acid rain. As such, US $\mathrm{NO}_{\mathrm{X}}$ regulations have focused on areas where these two problems are primary concerns - California (ozone) and the eastern United States (acid rain). For $\mathrm{NO}_{\mathrm{X}}$, the $1970 \mathrm{CAA}$ established a limit of $0.7 \mathrm{lbs} / \mathrm{mmBtu}$ of $\mathrm{NO}_{\mathrm{X}}$ for power plants (equivalent to $860 \mathrm{mg} / \mathrm{m}^{3}$ ). The 1977 CAA tightened the standard slightly, lowering the limit to 0.5-0.6 lbs/mmBtu (equivalent to $615-740 \mathrm{mg} / \mathrm{m}^{3}$ ). ${ }^{5}$ In addition, removal of at least $65 \%$ of $\mathrm{NO}_{\mathrm{X}}$ emissions was required.

It was not until the 1990s that $\mathrm{NO}_{\mathrm{X}}$ regulations were strengthened, and even then the focus was on regions of primary concern. First, the state of California established limits as low as $0.015 \mathrm{lb} / \mathrm{mmBtu}\left(18.45 \mathrm{mg} / \mathrm{m}^{3}\right.$ ) for the Los Angeles Basin beginning in 1991 (Alfonso et al. 2000). At the national level, the 1990 CAA established the Ozone Transport Commission (OTC), designed to address the regional problem of acid rain in the eastern US. The resulting plan, implemented in phases, called for reductions in affected eastern states to $0.2 \mathrm{lb} / \mathrm{mmBtu}$ (equivalent to $246 \mathrm{mg} / \mathrm{m}^{3}$ ) beginning in May 1999, and reductions to $0.15 \mathrm{lb} / \mathrm{mmBtu}$ (equivalent to $220 \mathrm{mg} / \mathrm{m}^{3}$ ) by May of 2003, and allowed trading of $\mathrm{NO}_{\mathrm{X}}$ emission permits across plants in

\footnotetext{
${ }^{5}$ Different limits applied depending on the type of coal burnt. The higher 0.6 limit applied to bituminous coal, which is most commonly used at US coal-fired electric plants.
} 
the region. ${ }^{6}$ The $1998 \mathrm{NO}_{\mathrm{X}}$ SIP Call expanded $\mathrm{NO}_{\mathrm{X}}$ reductions to 22 eastern states, and required that emissions reductions be in place by 2004. At the national level, the 1990 CAA tightened emission standards to as low as $0.4-0.46 \mathrm{lb} / \mathrm{mmBtu}\left(490-565 \mathrm{mg} / \mathrm{m}^{3}\right)$ by $2000 .^{7}$ Unlike previous legislation, these reductions applied to both new and existing plants.

\section{B. Japan}

Japan's air pollution regulations follow a similar trend to those of the US, with the exception that $\mathrm{NO}_{\mathrm{X}}$ emissions were regulated more quickly. National air pollution regulation in Japan began with the 1968 Air Pollution Control Law. This law set initial emissions standards for $\mathrm{NO}_{\mathrm{X}}$ and $\mathrm{SO}_{2}$. These standards were tightened by amendments in 1970 and 1974, which introduced formulas for additional emission reductions in "polluted regions". Within these regions, both total emissions in the region and plant-level emissions are regulated.

For $\mathrm{SO}_{2}$, emissions standards vary by plant, according to a formula that considers both the region's environmental quality and the "effective stack height" of the plant. ${ }^{8}$ Stricter standards apply for new plants in the most polluted regions. Standards for a sample plant with an effective stack height of 260 meters range from 245-1250 parts per million (ppm) (equivalent to $700-3600 \mathrm{mg} / \mathrm{m}^{3}$ ). For new plants in the most polluted regions, such as Tokyo the standard can be as low as $60 \mathrm{ppm}\left(170 \mathrm{mg} / \mathrm{m}^{3}\right)$. Compared to the US, Japanese regulations are stricter for sources in polluted areas, but weaker elsewhere.

\footnotetext{
${ }^{6}$ Affected states are Maine, New Hampshire, Vermont, Massachusetts, Connecticut, Rhode Island, New York, New Jersey, Pennsylvania, Maryland, Delaware, and the District of Columbia.

7 This regulation was phased in, with slightly higher standards between 1996 and 1999 . Also, note that the requirements vary by plant. The standards presented apply to tangentially-fired boilers and dry bottom wall-fired boilers respectively. These are the most common boiler types in the US. Other boilers are allowed more $\mathrm{NO}_{\mathrm{X}}$ emissions.

8 "Effective stack height" is the sum of both the actual stack height and the average plume rise height.
} 
In contrast, Japanese $\mathrm{NO}_{\mathrm{X}}$ regulations have been stricter than the US since the 1974 amendments to the Air Pollution Control Law. At that time, allowable $\mathrm{NO}_{\mathrm{X}}$ emissions from coal-fired power plants fell from $902 \mathrm{mg} / \mathrm{m}^{3}$ to $616 \mathrm{mg} / \mathrm{m}^{3}$, making Japan’s $\mathrm{NO}_{\mathrm{X}}$ standard nearly $30 \%$ stricter than the limits in place in the US at the time. Despite stricter regulations, $\mathrm{NO}_{\mathrm{X}}$ continued to be a problem in Japan. As a result, the $\mathrm{NO}_{\mathrm{X}}$ standard was tightened further in 1987, with a new limit of just $410 \mathrm{mg} / \mathrm{m}^{3}$. Moreover, unlike in the US, where older plants are grandfathered from new emission standards, these standards apply to both new and existing plants.

\section{Germany}

In contrast to the US and Japan, Germany ${ }^{9}$ implemented strict air pollution standards later. The Federal Immission Control Law of 1974 sets general principles for air pollution control, but specific limits were not set until the mid 1980's. For large (> $50 \mathrm{MWt}$ ) plants, the Ordinance on Large Combustion plants established emissions standards on June 1, 1983. Smaller plants (1-50 MWt) are covered by the Technical Instruction for Air Pollution Control, which was last amended in 1986. As a latecomer to air pollution regulation, Germany could potentially take advantage of advances made elsewhere. As such, the standards set in the 1980s were significantly stricter than those in the US or Japan. $\mathrm{NO}_{\mathrm{X}}$ emissions from the largest coalfired power plants (including existing plants) were limited to just $200 \mathrm{mg} / \mathrm{m}^{3}$. Similarly, $\mathrm{SO}_{2}$ emissions were limited to just $400 \mathrm{mg} / \mathrm{m}^{3}$. Both new and existing plants were expected to comply with these regulations by 1990. The federal government provided assistance through both research and tax benefits for plant expenditures on $\mathrm{NO}_{\mathrm{X}}$ control. These tax credits placed particular emphasis on the development of German-manufactured catalysts. For $\mathrm{SO}_{2}$, existing

\footnotetext{
${ }^{9}$ Prior to unification, this section describes laws passed in West Germany.
} 
plants were given until April 1, 1993 to meet these standards, and were only required to restrict emissions to $2000 \mathrm{mg} / \mathrm{m}^{3}$ in the interim. Upon unification, the states of the former East Germany adopted West German environmental standards. New plants would have to comply immediately, while existing plants from the former East Germany were given until 1996 to come into compliance with these regulations.

\section{Patent Data}

This paper uses patent data from the US, Japan, and Germany to study trends of innovation and technology transfer in response to $\mathrm{NO}_{\mathrm{X}}$ and $\mathrm{SO}_{2}$ regulations. These data come from various sources, including the EPO’s esp@cent database, the Japanese Patent Office’s website, the Delphion on-line patent database, the NBER patent citation database, and a set of CD-ROM’s from MicroPatent. Below I describe how the international patent system works, discuss how such data should be interpreted, and briefly describe construction of the dataset used in this paper. A description of patent citation data is presented in section V. Appendix A provides a more detailed discussion of the construction of the data for this paper.

\section{A. Using Patent Data}

Patents are granted by national patent offices in individual countries. Patent protection is only valid in the country that grants the patent. An inventor must file for protection in each nation in which protection is desired. Nearly all patent applications are first filed in the home country of the inventor. The date of the initial application is referred to as the priority date. If the patent is granted, protection begins from the priority date. Inventors who desire patent protection in other nations must file applications in those nations, either directly or by using a 
Patent Cooperation Treaty (PCT) that designates the countries in which protection is desired, within one year of the priority date. If the inventor does file abroad within one year, the inventor will have priority over any patent applications received in those countries since the priority date that describe similar inventions.

These additional filings of the same patent application in different countries are known as patent families. Because of the additional costs of filing abroad, along with the one-year waiting period that gives inventors additional time to gauge the value of their invention, only the most valuable inventions are filed in several countries. Moreover, filing a patent application in a given country is a signal that the inventor expects the invention to be profitable in that country. Because of this, researchers such as Lanjouw and Schankerman (1999) have used data on patent families as proxies for the quality of individual patents. Lanjouw and Mody (1996) use such data to show that environmental technologies patented by developed country firms are more general than similar inventions from developing countries, as the developed country inventions have larger patent families.

Using patent data offers several advantages. First, patent data from all three countries is readily available. Second, patent data is available in highly disaggregated forms. Whereas R\&D data is typically available only for specific industries or general applications, ${ }^{10}$ patent classifications can be used to distinguish, for example, between pollution control devices designed to reduce $\mathrm{NO}_{\mathrm{X}}$ emissions from devices designed to control $\mathrm{SO}_{2}$ emissions. Third, the number of countries in which an inventor seeks protection for an invention provides a measure of diffusion of the innovation. Fourth, economists have found that patents, sorted by their date of application, provide a good indicator of R\&D activity (see, for example, Griliches 1990).

\footnotetext{
${ }^{10}$ For example, in the US, R\&D data is available from 1972-1994 for air pollution control, but it is not broken down by pollutant.
} 
Nonetheless, when working with patent data, it is important to be aware of its limitations. The existing literature on the benefits and drawbacks of using patent data is quite large. ${ }^{11}$ For this research, it is particularly important to note that although the decision to file a patent obviously follows from the decision to perform R\&D, not all successful research results are patented. In return for receiving the monopoly rights inferred by a patent, the inventor is required to publicly disclose the invention. Rather than make this disclosure, inventors may prefer to keep an invention secret. Surveys of inventors indicate that the rate at which new innovations are patented varies across industry (Levin et al. 1987). Fortunately, when studying the development of a single technology, this is less of a concern than when using patent data to measure innovation trends across several dissimilar industries. ${ }^{12}$ Finally, it is also important to note that the quality of individual patents varies widely. Some inventions are extremely valuable, whereas others are of almost no commercial value. This is partly a result of the random nature of the inventive process. Accordingly, the results of this paper are best interpreted as the effect of an “average” patent, rather than any specific invention.

\section{B. Data Description}

When patents are granted, they are given technology classifications and subclassifications by various patent offices. These classifications can be used to identify patents pertaining to each

\footnotetext{
${ }^{11}$ Griliches (1990) provides a useful survey.

${ }^{12}$ One concern that remains is that the propensity to patent may vary over time. For example, the number of patents filed in recent years in the United States has risen dramatically. Some observers argue that at least part of this increase can be attributed to recent court decisions that have increased the value of patent protection. One possible control for this is to use the percentage of all successful domestic patent applications per year in each technology field as the measure of innovative activity. Using the percentage of applications in each field, rather than a raw count of applications, accounts for growth in the economy and exogenous changes in patenting behavior. Policy changes that affect all patent classifications would lead to a change in both the total number of patent applications and the number of pollution control patent applications in a given year. Results using this method were obtained, and no major changes in the trends described in section IV were found when these controls were made. As the application data were not available across all years, and because presenting data in percentages does not allow one to compare the magnitude of patenting activity across countries, the raw data are presented in section IV.
} 
of the technologies described in section IV. Traditional classification systems, such as the International Patent Classification (IPC) system or the US patent classification system, do not provide enough detail to distinguish among technologies at the level of detail needed for this paper. Thus, two alternative classification systems were used. For US and German patents, relevant patents were identified using the European Classification System (ECLA). The ECLA is based upon the IPC, but provides additional detail necessary to distinguish between the types of pollution controlled by various technologies. ECLA classifications are assigned to patent examiners at the European Patent Office (EPO). The EPO provides a searchable on-line database, esp@cenet, that includes ECLA classifications for all German patents and all US patents granted since $1920{ }^{13}$ However, the EPO database does not include complete updates of the ECLA for Japanese patents. Thus, Japanese patents were obtained from the Intellectual Property Digital Library on the Japan Patent Office (JPO) web site. ${ }^{14}$ The JPO does not use the ECLA. However, it uses its own system, the F-term, which, like the ECLA, provides greater detail than the IPC.

Using these two systems, we identified classifications relevant to the technologies described in section IV. This process is described in greater detail in appendix A. Appendix B lists the classifications used for each technology type. In choosing relevant classifications, particular care was taken to avoid classifications that were too broad - that is, where some patents in the class pertained to pollution control, but most did not. Using the on-line databases, we downloaded a list of patent numbers for documents published in the US, Germany, Japan,

\footnotetext{
${ }^{13}$ The database can be found at http://ep.espacenet.com/search97cgi/s97is.dll?Action=FormGen\&Template=ep/en/ home.hts

${ }^{14}$ This database can be found at http://www.ipdl.jpo.go.jp/homepg_e.ipdl.
} 
and the EPO. ${ }^{15,16}$ Once the relevant patents had been obtained, descriptive information on these patents was downloaded from the Delphion on-line database. These data are available for patents published in the US, Germany, or the EPO, but not for patents from Japan. Descriptive data downloaded include the application, priority, and issue date for each patent, the home country of the inventor, and data on patent families. Data on the year of application for Japanese patents was obtained from the JPO website. However, it is not possible to identify the home country of the inventor or the priority year for the Japanese patents in the dataset.

To organize the data, patents were sorted by priority year (or the application year for Japanese patents). As noted earlier, this date tends to correspond with the actual inventive activity. Moreover, as the average length of time it takes to process a patent application varies across countries, using priority dates, rather than the date of grant, provides a common date for comparisons across countries. Data from Japan and German includes both successful and unsuccessful patent applications, as all patent applications are published in each country 18 months after the initial filing. However, the US data includes only patent applications that were subsequently granted. Until 2001, patents were only published in the US upon grant, so that no public record exists of unsuccessful US patent applications. Finally, one caveat is necessary for interpreting Japanese data. Until 1988, Japanese patent law required a separate patent application for each unique claim on a patent. For example, the inventor of a bicycle would

\footnotetext{
${ }^{15}$ Before German unification, this only includes patents granted in West Germany. However, prior to unification, there are very few patents granted in West Germany to East German inventors. Moreover, there are no spikes in domestic patent counts after unification, suggesting that unification has little effect on the data.

${ }^{16}$ Beginning in 1978, an inventor desiring protection in Europe could file a single patent application through the EPO. The applicant designates as many of the $18 \mathrm{EPO}$ member-states for protection as desired. The application is examined by the EPO. If granted, the patent is transferred to the individual national patent offices designated for protection. Typically, a patent applicant first files for protection in their home country, and then applies to offices abroad, such as the EPO. The esp@cenet database returns patent numbers for patents with German priority that were also filed through the EPO, but does not return the German patent numbers for patents with foreign priority that were filed through EPO and designated Germany for protection. Thus, foreign patent counts in Germany are augmented by including EPO patents from non-German inventors that designate Germany for protection.
} 
require separate patents describing its various parts (Ordover 1991). In other countries, a single patent can use several claims to describe an invention. Thus, an invention that would result in one patent in other nations would result in many individual patents in Japan. Even today, Japanese patents tend to have fewer claims than US patents (Cohen et al. 2002). As such, while the data are useful to observe trends across time within countries, the level of patenting activity across countries are not directly comparable using patent data alone.

\section{Pollution Control Innovations Across Countries}

Using the patent data described above, this section examines innovations in pollution control technologies designed to reduce emission of $\mathrm{NO}_{\mathrm{X}}$ or $\mathrm{SO}_{2}$ from coal-fired power plants. I describe the technologies used to control these emissions, and look at patenting trends across the three countries. Of particular interest are the links between environmental policies in one nation and patenting activity in a second. Do environmental policies spur patenting activity from foreign researchers? Moreover, do foreign environmental regulations lead to patenting activity within a second country?

\section{A. $\mathrm{NO}_{X}$ Post Combustion}

$\mathrm{NO}_{\mathrm{X}}$ emissions can be controlled via modifications to the combustion process or by treatment of flue gas after combustion. The primary post-combustion techniques are selective catalytic reduction (SCR) and selective non-catalytic reduction (SNCR). In both processes, an ammonia-based regent is injected into the flue gas stream. A chemical reaction between the $\mathrm{NO}_{\mathrm{X}}$ gases and the regent produce nitrogen and water. SCR uses a catalyst to produce this reaction, allowing it to work at lower temperatures than SNCR technology. SCR has a higher 
capital cost than SNCR, but can reduce emissions by as much as $80-90 \%$, compared to just 30 40\% reduction from SNCR technologies. (CoalPower4 2001, Afonso et al., 2000) As such, SCR is the technology of choice for plants facing tight $\mathrm{NO}_{\mathrm{X}}$ emissions restrictions, such as in Germany and Japan. Table 1 shows the number of plants using post-combustion techniques versus those using combustion modification, taken from the CoalPower4 database. This database, available from the International Energy Agency’s Clean Coal Centre, includes coalfired plants in operation as of 2000. 51 of 87 (59\%) of Japanese coal-fired power plant units use post-combustion techniques to control $\mathrm{NO}_{\mathrm{X}}$ emissions, often in combination with combustion modification techniques. Similarly, 118 of 228 (52\%) plants in Germany use post-combustion methods. In contrast, just 44 post-combustion treatment techniques were in use in 1150 US units (3.8\%), although another 72 were planned or under construction in response to strengthened $\mathrm{NO}_{\mathrm{X}}$ regulations in the late 1990s.

The complexity of retrofitting SCR on an existing plant depends on both the level of reduction required and the quality of the coal burned. Higher flue gas sulfur and ash loadings make retrofitting more difficult in Germany than Japan. German boilers are more similar to US boilers than those in Japan, suggesting that lessons learned in Germany will be of particular use as US plants begin to adopt SCR technologies. (Frey 1995) This also suggests that innovations in one country need not apply to plants elsewhere.

Trends in patenting of post-combustion $\mathrm{NO}_{\mathrm{X}}$ control techniques across the US, Japan, and Germany show the importance of local influences. Figure 3 displays these patents for the United States. Beginning in 1973, when stricter Japanese $\mathrm{NO}_{\mathrm{X}}$ limits took effect, until 1988, when the 1990 CAA was being debated in Congress, as many or more successful $\mathrm{NO}_{\mathrm{X}}$ postcombustion patent applications filed in the US came from foreign sources as domestic sources in 
all but three years $(1978,1980$, and 1981). These trends are driven in large part by stricter regulations in Japan and Germany. Note that $\mathrm{NO}_{\mathrm{X}}$ post-combustion patents from Japan increase after passage of stricter $\mathrm{NO}_{\mathrm{X}}$ regulations in 1973, and German patents peak after passage of $\mathrm{NO}_{\mathrm{X}}$ regulations in 1984. Japanese patents also reach a second, lower peak after Japanese standards were tightened in 1987. In fact, at the peak level of patenting for each country, the number of patents from each country is greater than the number from US applicants in the same year! Furthermore, neither German nor Japanese patenting activity respond to the 1990 CAA. In contrast, domestic (US applicant) and total foreign patents do respond to the 1990 CAA. Domestic patents increase by a factor of 11 from a post-CAA low of 6 in 1982 to a peak of 68 in $1990 .^{17}$

Figure 4 displays the same data for Germany. Here, the links between domestic regulation and innovation are even more apparent. Domestic $\mathrm{NO}_{\mathrm{X}}$ post-combustion patent applications increase by a factor of 5.5 between 1983 and 1985, from 27 to 149. In contrast, total foreign applications merely double from 12 in 1983 to 24 in 1985 . Recall that the regulations passed in Germany in 1984 were significantly more stringent than $\mathrm{NO}_{\mathrm{X}}$ regulations elsewhere. Thus, new innovations were needed to achieve these goals. A look at international patenting activity of German inventors supports the notion that important innovations were taking place in response to these innovations. For German $\mathrm{NO}_{\mathrm{X}}$ post-combustion patents, an average of 30\% were also filed in Japan between 1970 and 2000, and 24\% were also filed in the United States. However, inventors of patents granted in the mid-1980s were more likely to file in Japan. In 1982, just 30.8\% such patents also sought protection in Japan. This figure rises to $37.0 \%$ in

\footnotetext{
${ }^{17}$ Note that the growth in US post-combustion patents also begins in the mid-1980s. This is likely in response to new standards passed for industrial sources of $\mathrm{NO}_{\mathrm{X}}$, rather than the German regulations. If these patents were in response to German regulations, we would expect to see a similar increase of US patent applications in Germany. As we will see in Figure 4, this is not the case.
} 
1983, $45.1 \%$ in 1984 , and $46.3 \%$ in 1985 . It drops back to $26.7 \%$ in 1986 , and doesn't reach 30\% again until 1992, suggesting that the prospects for truly important discoveries began to fall. This may explain the quick drop in patenting activity that occurs in the late-1980s. ${ }^{18}$ As evidence of the importance of regulation in the target country, note that there was no such increase in filings to the US, where there was little market for SCR technology due to laxer regulations. For example, only $17.4 \%$ of these German patents also filed for protection in the U.S. in 1985.

Finally, Figure 5 displays patent data for Japan. As noted earlier, breakdowns by the applicant's home country are not available for the Japanese patents. Once again, the importance of domestic regulations are important, as $\mathrm{NO}_{\mathrm{X}}$ post-combustion patents peak after $\mathrm{NO}_{\mathrm{X}}$ standards were tightened in 1973 and 1987. Note also that there is no evidence of Japanese inventors responding to regulatory changes in Germany during the mid-1980s. However, the increase in patenting activity in 1995 and 1996 may be a reaction to new regulations pending in the United States, as Japanese patents filed in the US at the same time experience a similar jump.

\section{B. $N O_{X}$ Combustion Modification Techniques}

In contrast to post-combustion techniques, combustion modification techniques are less costly, as they do not require add-on equipment. Rather, they involve changing the combustion process to reduce the amount of $\mathrm{NO}_{\mathrm{X}}$ formed by combustion. Typically, such modifications work by adjusting the mix of air and fuel used in combustion, which reduces the peak flame temperature and results in lower $\mathrm{NO}_{\mathrm{X}}$ formation. Commonly used techniques include low- $\mathrm{NO}_{\mathrm{X}}$ burners (LNB) and overfire air (OFA), in which combustion air is separated into primary and

\footnotetext{
${ }^{18}$ Popp (2002) uses patent citations to support a similar story for US energy innovation in response to higher energy prices during the 1970s and 1980s.
} 
secondary flows. These techniques reduce emissions by $30-40 \%$ from uncontrolled levels (CoalPower4 2001, Afonso et al. 2000). Other techniques used include flue gas recirculation (FGR), in which some of the flue gas is recirculated and mixed with combustion air. On its own, this technique reduces emissions by approximately 20\%. Thus, it is often used in combination with other techniques. Finally, fuel staging techniques, such as reburning, use a secondary fuel directed at a section of the furnace. The secondary fuel breaks down and reacts with $\mathrm{NO}_{\mathrm{X}}$ produced by the primary combustion process. A third, final combustion stage then burns remaining carbon monoxide and hydrocarbons produced by this second stage. Reburning can reduce emissions by as much as $70 \%$, particularly when paired with other techniques, such as SCNR (CoalPower4 2001, Afonso et al. 2000).

Compared to post-combustion techniques, combustion modification techniques are used in all three countries. One difference, as shown in Table 1, is the majority of plants using combustion modification in Germany or Japan also make use of post-combustion techniques. In contrast, only 22 of the 437 plants using combustion modification in the US also use postcombustion techniques. Patenting trends reflect these usage patterns. Figure 6 shows these trends for the US. While all three countries have some combustion modification patents, the US holds a greater share of such patents. Unlike the post-combustion techniques, there are more domestic than foreign patents within the US in nearly every year. Japanese and German patents filed in the US remain low even after the passage of regulations in each country. For example, German combustion modification patents peak at just 5 in 1985. Japanese patents peak at 8 in 1995, and peak at just 6 after passage of Japanese $\mathrm{NO}_{\mathrm{X}}$ regulations in the 1970s. This compares to post-combustion peaks of 29 patents for Germany and 31 for Japan. In comparison, US combustion modification patents peak at 36 in 1991. Moreover, there is little US patenting until 
the late 1980s, when negotiations for the 1990 CAA began, providing further evidence that stringency of regulation is important for inducing innovation.

In Japan and Germany, even domestic combustion modification patents show little response to policy. There is an increase in combustion modification patents in Japan after passage of $\mathrm{NO}_{\mathrm{X}}$ regulations in 1973, but the increase is not as strong as exists for either postcombustion techniques or $\mathrm{SO}_{2}$ control technologies. Similarly, as shown in Figure 7, combustion modification patents in Germany do rise in the 1980s, but the response is more gradual than for post-combustion techniques. Moreover, the level of patenting activity remains relatively constant through the 1990s. These patents are no more likely to file for protection in the US than patents from other years, so this is less likely to be a response to $\mathrm{NO}_{\mathrm{X}}$ regulations in the US than a response to the deadline for plants from the former East Germany to comply with emissions regulations.

\section{Sulfur Dioxide}

Sulfur dioxide from coal-fired power plants can be reduced by switching to cleaner coal or using flue gas desulfurization (FGD) units, commonly known as "scrubbers". The most common scrubber technology is the wet scrubber. In a wet scrubber, a sorbent, usually lime or limestone, is injected into a vessel to interact with the flue gas. The chemical reaction creates a sludge, which must be disposed of. A second chemical reaction can convert the sludge into gypsum, which can be sold. Removal efficiencies as high as 99\% are possible (CoalPower4 2001).

As with $\mathrm{NO}_{\mathrm{X}}$, the timing of $\mathrm{SO}_{2}$ patenting activity follows regulatory trends in each country. Figure 8 shows that $\mathrm{SO}_{2}$ patents in the US respond to passage of the CAAs, reaching 
peaks in 1979 (after passage of the 1977 CAA requiring scrubbers) and 1994 (immediately before the beginning of the $\mathrm{SO}_{2}$ permit program in 1995). A similar spike occurs in the mid1970s in Japan. As Popp (2003) notes, the nature of innovation changed during this time, as the scrubber mandate focused innovation on lowering the costs of compliance, rather than improving efficiency. In comparison, permit trading increased the rewards for installing more efficient scrubbers, so innovation after the 1990 CAA had a greater effect on the removal efficiency of scrubbers. Unlike $\mathrm{NO}_{\mathrm{X}}$, we see little increase in patents from either Japan or Germany applicants in the US, even though there are spikes in patenting activity in each country corresponding with the implementation of $\mathrm{SO}_{2}$ standards. There is a small jump in German $\mathrm{SO}_{2}$ patents in 1982, but the increase is not as noticeable as with $\mathrm{NO}_{\mathrm{X}}$ technologies. It may be that, since the US was also regulating $\mathrm{SO}_{2}$ emissions, and thus innovating at the same time as Japan and Germany, these foreign innovations were not perceived as unique enough to also enter the US market. Finally, note that although Japanese and German $\mathrm{SO}_{2}$ patents do not increase much, there is an increase in total foreign patents during the late 1980s. These patents come from other EPO nations, and correspond with passage of the Directive on Controlling of Emissions from Large Combustion Plants by the European Community in 1988, which established minimum $\mathrm{SO}_{2}$ standards for European countries (McConville 1997).

This jump in European patents also affects Germany, as shown in Figure 9. Other than this spike in European patenting efforts, German $\mathrm{SO}_{2}$ patenting trends follow those of $\mathrm{NO}_{\mathrm{X}}$, in that German inventors are active after the implementation of standards in 1984, but inventors from Japan and the US do not respond. Moreover, there is not much patenting activity from Japan and the US in the 1970s, despite higher activity levels in each country. Also, unlike $\mathrm{NO}_{\mathrm{X}}$ post-combustion techniques, German inventors tended not to seek protection in Japan and the 
US, even during the spike of patenting in the mid-1980s. At peak patenting levels in 1983, just $12 \%$ of German applicants for $\mathrm{SO}_{2}$ patents also filed in Japan, and just $17 \%$ in the US. This compares to over $37 \%$ who filed for protection of $\mathrm{NO}_{\mathrm{X}}$ post-combustion techniques in Japan. In this case, as a latecomer to $\mathrm{SO}_{2}$ regulation, German innovations simply do not appear as important as those from Japan or the US.

\section{Do Knowledge Spillovers Occur?}

A cursory look at the patent data suggests any spillovers that do occur across countries in these technologies are indirect. In each country, firms respond to stricter environmental standards by increasing innovation. This remains true even for countries that are latecomers to regulations, such as the US for $\mathrm{NO}_{\mathrm{X}}$ and Germany for $\mathrm{SO}_{2}$. This suggests that these latecomers are not simply taking advantage of innovations done elsewhere. As further evidence of this, note that the suppliers of both $\mathrm{NO}_{\mathrm{X}}$ post-combustion pollution control techniques in the US and $\mathrm{SO}_{2}$ scrubbers in Germany (both cases of late adoption of regulation) are primarily domestic companies, as shown in Table 2. This does not necessarily mean, however, that these follower countries reap no benefits from earlier foreign innovations, as such innovations may influence the $R \& D$ done in each of the follower nations. Such transfers represent true knowledge spillovers, as the knowledge represented by the cited patent creates a positive externality knowledge which is borrowed and improved upon by the domestic inventor (Griliches 1979).

This section uses patent citation data for pollution control patents granted in the US to test for such knowledge spillovers. When a patent is granted, it contains citations to earlier patents that are related to the current invention. The citations are placed in the patent after consultations among the applicant, his or her patent attorney, and the patent examiner. It is the 
applicant's responsibility to list any related previous patents of which he or she is aware. In addition, the examiner, who specializes in just a few patent classifications, will add other patents to the citations, as well as subtracting any irrelevant patents cited by the inventor. Patent citations narrow the reach of the new patent by placing the patents cited outside the realm of the current patent, so it is important that all relevant patents be included in the citations. ${ }^{19}$ For the same reason, inventors have an incentive to make sure that no unnecessary patents are cited. As a result, the previous patents cited by a new patent should be a good indicator of previous knowledge that was utilized by the inventor. ${ }^{20}$

The analysis requires data on every citation made by the patents in the pollution control database. These come from two sources. The NBER patent database (Hall, Jaffe, and Tratjenberg 2001) contains all patents made by US patents granted from 1976-1999. It also includes descriptive data on patents granted since 1963. Data from CD’s available from MicroPatent were used to update the citation records from 2000-2003. These two sources were used to create pairs of citing and cited patents for all of the pollution control patents. Descriptive data such as the year of grant and application, the inventor's home country, and the technology class of each cited patent were also included. In addition to patents for $\mathrm{NO}_{\mathrm{X}}$ post-combustion control, combustion modification, and $\mathrm{SO}_{2}$ control, I also include a broader group of general air pollution control patents. The patent classifications of this broader group are included in Appendix B.

\footnotetext{
19 "Outside the realm" means that the patent holder cannot file an infringement suit against someone whose invention infringes on qualities of the patented invention that were also included in patents cited by the patent holder.

${ }^{20}$ The key assumption here is that a citation made to a previous patent indicates a flow of knowledge from the cited patent to the citing patent, so that patents cited more frequently are considered more valuable to future inventors. Jaffe, Fogarty, and Banks (1998) investigate the validity of this assumption, using evidence from citations made to NASA patents. They conclude that, although there is noise in the citation process, aggregate citation patterns represent knowledge spillovers, although the spillover may be indirect.
} 
In making a formal analysis of patent citations, a simple count of subsequent citations is not enough, for the raw number of citations to any patent depends on the total number of patents that follow. Instead, it is necessary to look at the probability of citation. To prepare the data, I sort potentially cited patents for each pollution control technology by the year in which the patent was granted. I denote this year CTD, for “year cited.” Since a patent application is not made public in the U.S. unless the patent is granted, the year of grant is the year in which the patented innovation entered the public domain. Citing patents, denoted CTG, are sorted by year of application. Sorting by the year of application corresponds with the knowledge available to the inventor at the time the innovation was made, and allows the results to correspond to the counts of patent applications described in the preceding section.

One issue is considering which patents comprise the pool of potentially cited patents for each technology group. In general, patent citations within a field come from a narrow range of patents. For example, one would expect pollution control patents to cite inventions made in chemistry or combustion, but not in sewing, agriculture, or medicine. Thus, considering the entire universe of patents granted in a given year overstates the pool of potentially cited patents. This is important, since the size of the pool of potentially cited patents should vary over time as outside forces change incentives for innovation in a given field. I narrow the pool of cited patents by considering patents from only the most cited US patent classifications for each technology group. Data on the US patent classification of each cited patent comes from the NBER patent database. Table 3 shows the classifications considered as potentially cited patents for each technology, along with the percentage of citations made by patents in the group that cite patents in that classification. In general, these groups include over two-thirds of all citations 
made, although the figure is slightly lower for the more general air pollution control group. Only cited patents included in these US classifications are included in the subsequent analysis. ${ }^{21}$

In principle, regression analysis could be used on each individual patent in the data set. However, since most patents are never cited, the dependent variable is zero for most individual patents. Instead, I use the model first develop by Adam Jaffe and his co-authors and sort the data into groups of patents that could potentially cite each other (Caballero and Jaffe 1993, Jaffe and Trajtenberg 1996, 1999). For each combination of citing and cited years, separate groups are constructed for each technology, $i$; each citing country, $l$; and each cited country L. In each case, the countries considered are the US, Japan, Germany, and all other countries. Thus, one possible group includes citations made by US $\mathrm{NO}_{\mathrm{X}}$ post-combustion patents applied for in 1996 to US $\mathrm{NO}_{\mathrm{X}}$ post-combustion patents granted in 1994. Another such cohort would include citations made by US $\mathrm{NO}_{\mathrm{x}}$ post-combustion patents applied for in 1996 to Japanese $\mathrm{NO}_{\mathrm{x}}$ post-combustion

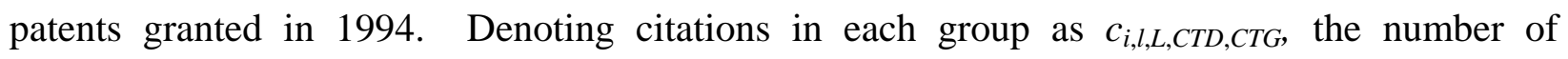
potentially cited patents applied for in year CTD as $n_{i, L, C T D}$, and the number of potentially citing patents granted in year $C T G$ as $n_{i, l, C T G}$, the probability of citation, $p$, for patents within each group is:

$$
p_{i, l, L, C T D, C T G}=\frac{c_{i, l, L, C T D, C T G}}{\left(n_{i, L, C T D}\right)\left(n_{i, l, C T G}\right)},
$$

To estimate the likelihood of citation for various groups of patents, it is necessary to control for factors that affect the likelihood of citation. Following the work of Jaffe and his coauthors, I estimate the probability of citation using an exponential distribution to model flows of knowledge. In this model, the probability of citation is written as:

\footnotetext{
${ }^{21}$ Results using all patents as potentially cited patents are similar, and are available from the author by request.
} 
(2) $p(i, l, L, C T G, C T D)=\alpha_{i} \alpha_{C T D} \alpha_{C T G} \alpha_{i, l, L}\left[1+\phi_{L} * d u m N O X P\right] \exp \left[-\beta_{1}(C T G-C T D)\right]\left[1-\exp \left(-\beta_{2}(C T G-\right.\right.$

CTD)) $]+\varepsilon$.

$\beta_{1}$ represents the rate of decay of knowledge as it becomes obsolete, and $\beta_{2}$ stands for the rate at which newly produced knowledge, as represented by a newly-patented innovation, diffuses through society. Parameters capturing attributes of the citing or cited patents that may influence the probability of citation, represented by the $\alpha$ parameters, include: ${ }^{22}$

- the likelihood of citation to patents from various years $\left(\alpha_{C T D}\right),{ }^{23}$

- the frequency with which patents applied for in the citing year cite earlier patents $\left(\alpha_{C T G}\right),{ }^{24,25}$

- the likelihood of citations within each technology group $\left(\alpha_{i}\right)$, and

- the frequency of citations within each citing-cited country pair $\left(\alpha_{l, L}\right)$.

For this paper, it is this last set of variables that is of primary interest. Flows of citations across countries provide evidence of disembodied technology transfer - that is, the direct transfer of ideas. Jaffe and Trajtenberg (1999) use this framework to look at citation patterns across a broad range of technologies, as their paper includes citations made by all US patents. They find that patents are most likely to cite other patents assigned to inventors from the same country.

${ }^{22}$ Although the model requires us to estimate attributes associated with the cited year, the citing year, and the lag between them, it is possible to identify attributes related to all three because the age of patents enters the model nonlinearly.

${ }^{23}$ This parameter can be seen as capturing variations in the usefulness of knowledge across time. Using a similar specification, Popp (2002) finds that this parameter declines over time for energy patents, suggesting diminishing returns to research over time.

${ }^{24}$ Changes in citing behavior over time must be accounted for because of institutional changes at the patent office that make patents more likely to cite earlier patents than was previously true, even if all other factors are equal. In particular, two changes have played an important role. First, computerization of patent office records has made it easier for both patent examiners and inventors to locate other patents similar to the current invention. Second, increasing legal pressure has made it more important for examiners to be sure that all relevant patents are cited.

${ }^{25}$ Although in principle citing and cited parameters could be estimated for every year, the model does not converge when that is attempted. Thus, citing parameters are grouped into four-year intervals, and cited parameters into fiveyear intervals. 
They also find US patents more likely to cite patents assigned to Japanese inventors than to German inventors, although US inventors are 38\% less likely to cite Japanese inventions as other American inventions.

In section IV, we saw that Japanese inventors were the first to invest substantial resources in $\mathrm{NO}_{\mathrm{X}}$ post-combustion pollution control techniques. The bracketed term $1+\phi_{\mathrm{L}} *$ dumNOXP tests whether there are differences in the flows of knowledge to the United States for these technologies. dumNOXP is a dummy variable equal to one for $\mathrm{NO}_{\mathrm{X}}$ post-combustion techniques. $\phi_{L}$ captures the additional likelihood of US inventors citing a patent from country $L$ for this technology. Positive estimates mean that citations are more likely to country $L$ for $\mathrm{NO}_{\mathrm{X}}$ postcombustion techniques. This is interpreted as a greater flow of knowledge into the US from country $L$ for this technology.

I estimate equation (2) using non-linear least squares. Because the data are grouped, I weight each observation by $\sqrt{\left(n_{i, L, C T D}\right)\left(N_{i, l, C T G}\right)}$ to avoid problems with heteroskedasticity (Greene 1993). For purposes of identification, one parameter of each type is normalized to $1 .{ }^{26}$

Table 4 presents the results of this estimation. Results of the parameters for citing and cited years, as well as the rates of decay and diffusion, are similar to those found in the papers by Jaffe and others. Of interest here are the patterns of citations across countries. Overall, inventors are more likely to cite other patents from their own country. For US inventors of pollution control technologies, they are about 40 percent less likely to cite patents from any other country, with Germany receiving the next most citations. Japanese inventors are equally likely to cite American and Germany patents. German inventors, however, are twice as likely to cite

\footnotetext{
${ }^{26}$ These are $\mathrm{SO}_{2}$ citing patents, citing year 1974-1977, cited year 1963-1968, and US citing US. For the $\mathrm{NO}_{\mathrm{x}}$ postcombustion term, US citing US is normalized to 0 .
} 
Japanese inventors as American inventors. Inventors from other nations make slightly more use of knowledge from the US and Germany than from Japan.

Of particular interest is whether the pattern of knowledge flowing into the US changes for $\mathrm{NO}_{\mathrm{X}}$ post-combustion patents. Here, we see that Japanese patents do provide a more important source of knowledge for this technology. Japanese patents are 61 percent more likely to be cited by American inventors for this technology. The overall likelihood of citation, relative to patents from US inventors, is found by multiplying this result by the overall coefficient for US/Japanese citing/cited pairs. This equals 0.95 , revealing that Japanese $\mathrm{NO}_{\mathrm{X}}$ post-combustion patents are just five percent less likely to be cited by US inventors than similar patents from other US inventors. German patents experience no significant differences for this technology, and patents from other countries are less likely to be cited for this technology.

To explore this further, Table 5 shows the result of analogous dummy variables for three alternative specifications. Column (1) shows the results just discussed. Column (2) presents a model with separate dummy variables for $\mathrm{NO}_{\mathrm{X}}$ post-combustion patents granted before or after 1990, the year in which the last Clean Air Act was passed. To see if the results for $\mathrm{NO}_{\mathrm{X}}$ postcombustion patents are truly unique, column (3) also includes a dummy variable for $\mathrm{SO}_{2}$ patents. Finally, column (4) includes both technologies and the pre-or-post 1990 dummies.

Turning first to column (2), we see the particular importance of the early Japanese patents. Japanese $\mathrm{NO}_{\mathrm{X}}$ post-combustion patents are more than twice as likely to be cited by American inventors as other Japanese patents. In fact, interacting this term with $\alpha_{U S, J a p}$, we see that these early Japanese patents are 91 percent more likely to be cited than American $\mathrm{NO}_{\mathrm{X}}$ postcombustion patents! In columns (3) and (4), we see that the basic patterns for $\mathrm{NO}_{\mathrm{X}}$ postcombustion patents hold when the $\mathrm{SO}_{2}$ dummies are also included in the model. The $\mathrm{SO}_{2}$ 
dummies are only significant for Japan and other nations. However, the effects are much smaller, with citation probability increases of just 15 percent. In each case, US patents remain the top source of knowledge flows for $\mathrm{SO}_{2}$.

\section{Conclusion}

This paper uses patent data from the US, Japan, and Germany to study international technology transfer of pollution control technologies. I find that inventors respond to domestic regulatory pressures, but not foreign regulatory pressures. There is little increase in foreign patents in either the US or Germany in response to increased emissions standards for $\mathrm{NO}_{\mathrm{X}}$ or $\mathrm{SO}_{2}$. There are, however, increases in patents from foreigners when regulations in the respective home countries increase. Thus, foreign regulatory pressures do increase the knowledge stock of a country.

However, at least for the technologies studied here, the resulting technology transfer is indirect. There is no evidence of domestic firms directly adopting these foreign technologies. First, even for countries that enact regulations late, such as the US for $\mathrm{NO}_{\mathrm{X}}$ or Germany for $\mathrm{SO}_{2}$, domestic innovative activity still increases after new regulations are passed. Second, domestic utilities do not purchase equipment from foreign suppliers, who have greater experience with these technologies, but rather from domestic firms. Nonetheless, using patent citation data from the US, I show that earlier foreign patents do play an important role as building blocks for domestic inventors.

These findings have important implications for the relationship between environmental policy and technological change. It suggests that diffusion of environmental technologies across borders will be slowed by the need for domestic R\&D to adapt these technologies to local 
markets. Moreover, for large-scale models of environmental policy and induced technological change, it suggests that domestic and foreign $\mathrm{R} \& \mathrm{D}$ are imperfect substitutes. Thus, it is not enough to model knowledge stocks as a combination of domestic and foreign innovative activity. Functional forms that require some level of domestic innovation before adoption of foreign technologies should be used.

Finally, it is useful to consider the generalizability of these results. It is particularly striking that even a technological leader like the US does not take direct advantage of foreign technologies. Still, further research on technology transfer between developed and developing countries is needed. We would expect there to be greater differences in technological sophistication between developing and developed countries than between the US, Japan, and Germany. This has two conflicting implications for applying these results to transfer from developed to developing countries. First, greater differences in currently-used technologies suggest that adopting the technology to local circumstances will be even more important for developing countries. However, less technological sophistication in developing countries may hamper the ability to make such modifications, and make developing countries more willing to accept "imperfect fits" of technology, rather than do adaptive R\&D. For example, Lanjouw and Mody (1996) find developing countries are more likely to patent water pollution control devices than air pollution control, and explain this difference by noting that water treatment plants must operate under many different types of local conditions. They also find variation in patenting levels across countries. Some countries, such as Brazil, experience significant increases in environmental patenting in their study. Other, such as South Korea, patent less, choosing instead to import pollution control technology from abroad. More detailed analysis of such differences would be of great use to both policymakers and economists alike. 


\section{REFERENCES}

Ahmad, Syed (1966), “On the Theory of Induced Innovation,” Economic Journal, 76(302), 34457.

Afonso, Rui, Marika Tatsutani, T.J. Roskelley, and Praveen Amar (2000), "The Regulation of $\mathrm{NO}_{\mathrm{X}}$ Emissions from Coal-Fired Boilers: A Case Study,” in Environmental Regulation and Technology Innovation: Controlling Mercury Emissions from Coal-Fired Boilers, Northeast States for Coordinated Air Use Management, Boston, MA.

Binswanger, Hans P. (1978a), “The Microeconomics of Induced Technical Change,” in Hans P. Binswanger and Vernon W. Ruttan, eds., Induced Innovation: Technology, Institutions, and Development, Baltimore, MD: John Hopkins University Press, 91-127

Binswanger, Hans P. (1978b), “Issues in Modeling Induced Technical Change,” in Hans P. Binswanger and Vernon W. Ruttan, eds., Induced Innovation: Technology, Institutions, and Development, Baltimore, MD: John Hopkins University Press, 128-63.

Binswanger, Hans P. (1974), “A Microeconomic Approach to Innovation,” Economic Journal, 84(336), 940-58.

Brunnermeier, Smita B. and Mark A. Cohen (2003), "Determinants of environmental innovation in US manufacturing industries," Journal of Environmental Economics and Management, 45(2), 278-293.

Buonanno, Paolo, Carlo Carraro, and Marzio Galeotti (2003), “Endogenous Induced Technical Change and the Costs of Kyoto,” Resource and Energy Economics, 25(1), 11-34.

Caballero, Ricardo J. and Adam B. Jaffe (1993), “How High are the Giants' Shoulders: An Empirical Assessment of Knowledge Spillovers and Creative Destruction in a Model of Economic Growth,” in Olivier J. Blanchard and Stanley Fischer, eds., NBER Macroeconomics Annual 1993, Cambridge, MA: MIT Press, 15-74.

CoalPower4 (2001), CD-ROM database available from the International Energy Agency Clean Coal Centre.

Cohen, Wesley M., Akira Goto, Akiya Nagata, Richard R. Nelson, and John P. Walsh (2002), "R\&D spillovers, patents, and the incentives to innovate in Japan and the United States," Research Policy, 31(8-9), 1349-1367.

Cohen, Wesley M. and Daniel A. Levinthal (1989), "Innovation and Learning: The Two Faces of R\&D,” The Economic Journal, 99, 569-596.

Ellerman, A. Denny, Richard Schmalensee, Paul L. Joskow, Juan Pablo Montero, and Elizabeth M. Bailey (1997), Emissions Trading Under the U.S. Acid Rain Program: Evaluatin of Compliance Costs and Allowance Market Performance, Cambridge, MA: MIT Center for Energy and Environmental Policy Research.

Frey, H. Christopher (1995), "Engineering-Economic Evaluation of SCR NOX Control Systems for Coal-Fired Power Plants," Proceedings of the American Power Conference, 57(2), 1583-1588. 
Goulder, Lawrence H. and Stephen H. Schneider (1999), "Induced Technological Change and the Attractivenes of $\mathrm{CO}_{2}$ Emissions Abatement," Resource and Energy Economics, 21, 211-253.

Greene, William H. (1993), Econometric Analysis, New York: Macmillan Publishing Co.

Grilichez, Zvi (1995), "R\&D and Productivity: Econometric Results and Measurement Issues,” in Paul Stoneman ed., Handbook of the Economics of Innovation and Technological Change, Malden, MA: Blackwell Publishers, 52-89.

Griliches, Zvi (1990), “Patent Statistics As Economic Indicators: A Survey,” Journal of Economic Literature, 28(4), 1661-707.

Griffith, Rachel, Stephen Redding, and John Van Reenen (2003), "R\&D and Absorptive Capacity: Theory and Empirical Evidence,” Scandinavian Journal of Economics, 105(1), 99-118.

Hall, Bronwyn, Adam B. Jaffe, and Manuel Tratjenberg (2001), “The NBER Patent Citation Data File: Lessons, Insights and Methodological Tools,” NBER Working Paper 8498.

Hicks, John R. (1932), The Theory of Wages, London: Macmillan.

Jaffe, Adam B., Michael S. Fogarty, and Bruce A. Banks (1998), "Evidence from Patents and Patent Citations on the Impact of NASA and Other Federal Labs on Commercial Innovation,” Journal of Industrial Economics, 46, 183-205.

Jaffe, Adam B., Rebecca Henderson, and Manuel Trajtenberg (1993), "Geographic Localization of Knowledge Spillovers as Evidenced by Patent Citations," Quarterly Journal of Economics, 108(3), 577-98.

Jaffe, Adam B. and Karen Palmer (1997), "Environmental Regulation and Innovation: A Panel Data Study,” Review of Economics and Statistics, 79(4), 610-19.

Jaffe, Adam B. and Manuel Trajtenberg (1999), "International Knowledge Flows: Evidence from Patent Citations,” Economics of Innovation and New Technology, 8, 105-36.

Jaffe, Adam B. and Manuel Trajtenberg (1996), "Flows of Knowledge From Universities and Federal Labs: Modeling the Flow of Patent Citations Over Time and Across Institutional and Geographic Boundaries," Proceedings of the National Academy of Sciences, 93, 12671-77.

Johnson, Daniel K.N. and David Popp (2003), "Forced Out of the Closet: The Impact of the American Inventors Protection Act on the Timing of Patent Disclosure," RAND Journal of Economics, 34(1), 96-112.

Kamien, Morton I. and Schwartz, Nancy L. (1968), “Optimal Induced Technical Change,” Econometrica, 36(1), 1-17.

Keller, Wolfgang (2001), “International Technology Diffusion,” NBER Working Paper \#8573.

Kemp, René (1997), Environmental Policy and Technological Change: A Comparison of the Technological Impact of Policy Instruments, Edward Elgar Publishing, Cheltenham, UK.

Lanjouw, Jean O. and Ashoka Mody (1996), "Innovation and the International Diffusion of Environmentally Responsive Technology,” Research Policy, 25, 549-71. 
Lanjouw, Jean O. and Mark Schankerman (1999), "The Quality of Ideas: Measuring Innovation with Multiple Indicators,” NBER Working Paper \#7345.

Levin, Richard C., Alvin K. Klevorick, Richard R. Nelson, and Sidney G. Winter (1987), “Appropriating the Returns from Industrial Research and Development," Brookings Papers on Economic Activity, 3, 783-820.

McConville, Alessandra (1997), Emission standards handbook, London: IEA Coal Research.

Newell, Richard G., Adam B. Jaffe, and Robert N. Stavins (1999), “The Induced Innovation Hypothesis and Energy-Saving Technological Change,” Quarterly Journal of Economics, 114, 941-975.

Popp, David (2004), "ENTICE: Endogenous Technological Change in the DICE Model of Global Warming,” Journal of Environmental Economics and Management, 48(1), 742768.

Popp, David (2003), “Pollution Control Innovations and the Clean Air Act of 1990," Journal of Policy Analysis and Management, 22(4), 641-660.

Popp, David (2002), “Induced Innovation and Energy Prices,” American Economic Review, 92(1), 160-180.

Porter, Michael E. and Claas van der Linde (1995), "Toward a New Conception of the Environment-Competitiveness Relationship,” Journal of Economic Perspectives, 9(4), 97-118.

Sloss, Lesley L. (2003), Trends in emission standards, London: IEA Coal Research.

Soud, Hermine N. (1991), Emission standards handbook: air pollutant standards for coal-fired power plants, London: IEA Coal Research.

Vernon, Jan L. (1988), Emission standards for coal-fired plants: air pollutant control policies, London: IEA Coal Research. 
Figure 1 - Theoretical Framework

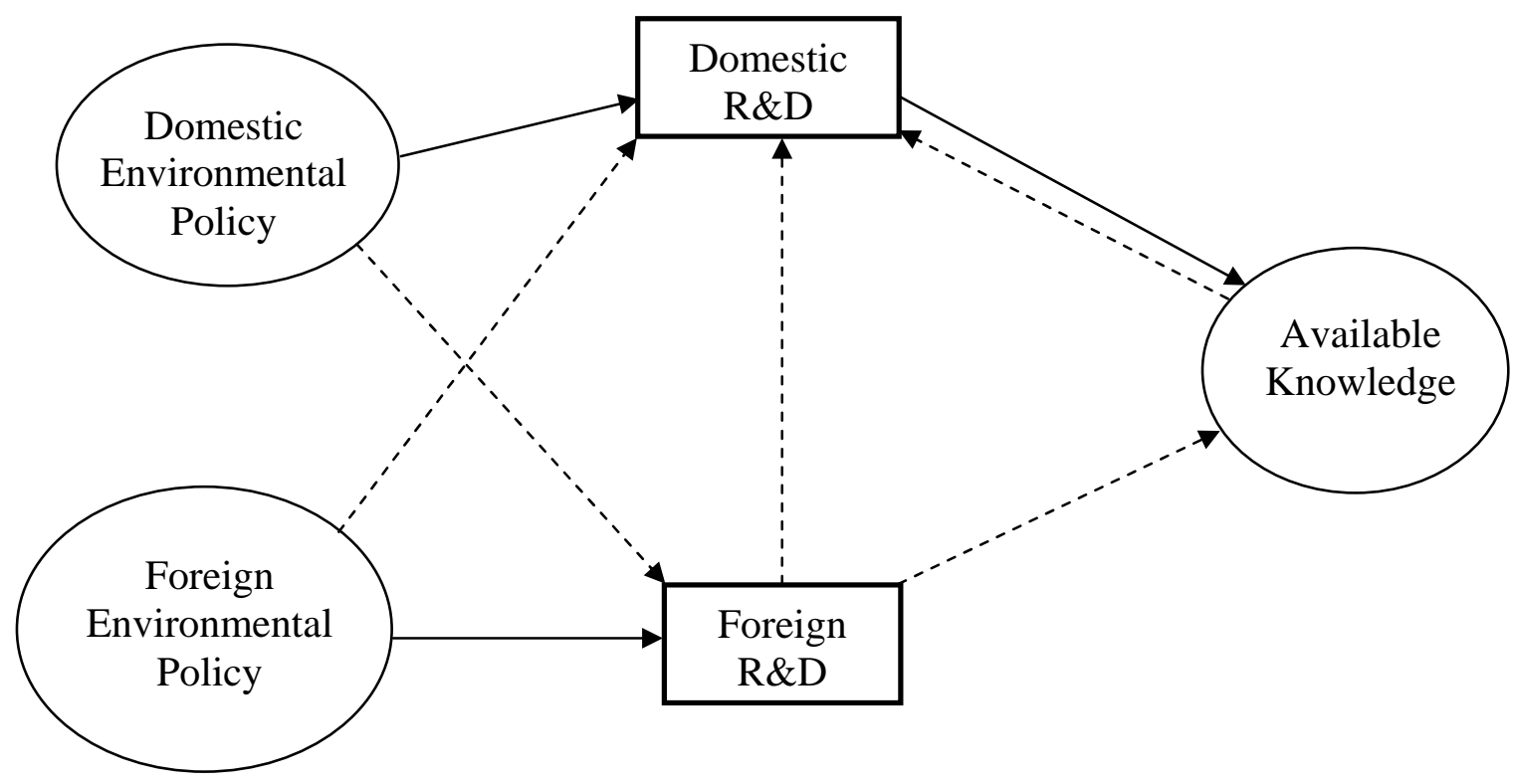

Figure 1 presents a schematic of the theoretical framework for this proposal. In the diagram, boxes represent endogenous variables chosen by firms and circles represent exogenous variables. Solid lines represent linkages well-established in the literature. Broken lines are links that are less established, and are thus the focus of this study. 
Figure 2 - Summary of $\mathrm{NO}_{\mathrm{X}}$ regulations

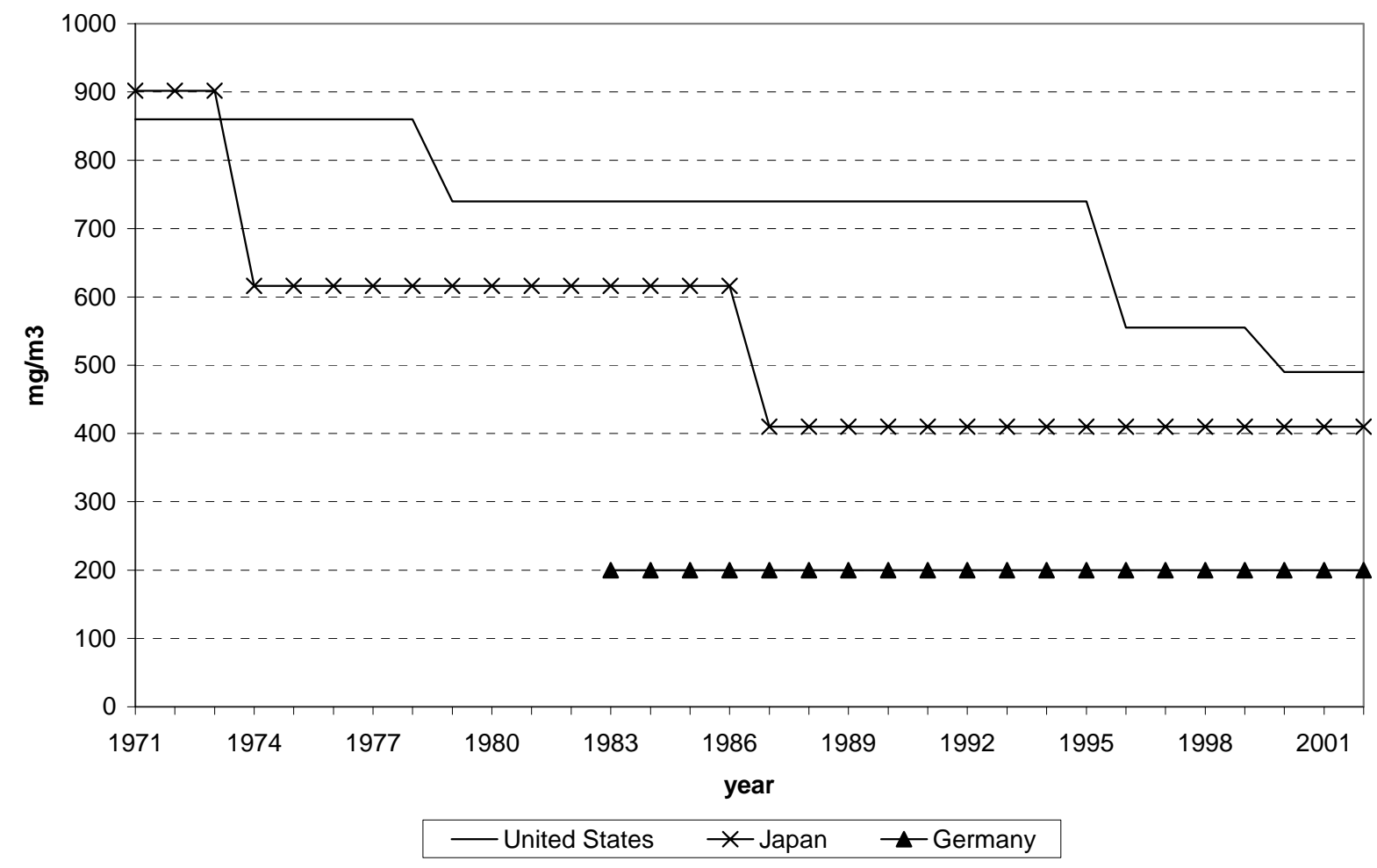

The figure shows changes in allowed levels of $\mathrm{NO}_{\mathrm{X}}$ emissions for power plants in the United States, Japan, and Germany. Note that there are no regulations in Germany until June of 1983. Until 1996, US law only applies to new plants, whereas both new and existing plants must comply with these regulations in Japan and Germany. Also note that lower standards were in place in southern California and the eastern United States during the 1990s. 


\section{Figure $3-\mathrm{NO}_{\mathrm{X}}$ Post-Combustion Patents in the United States}

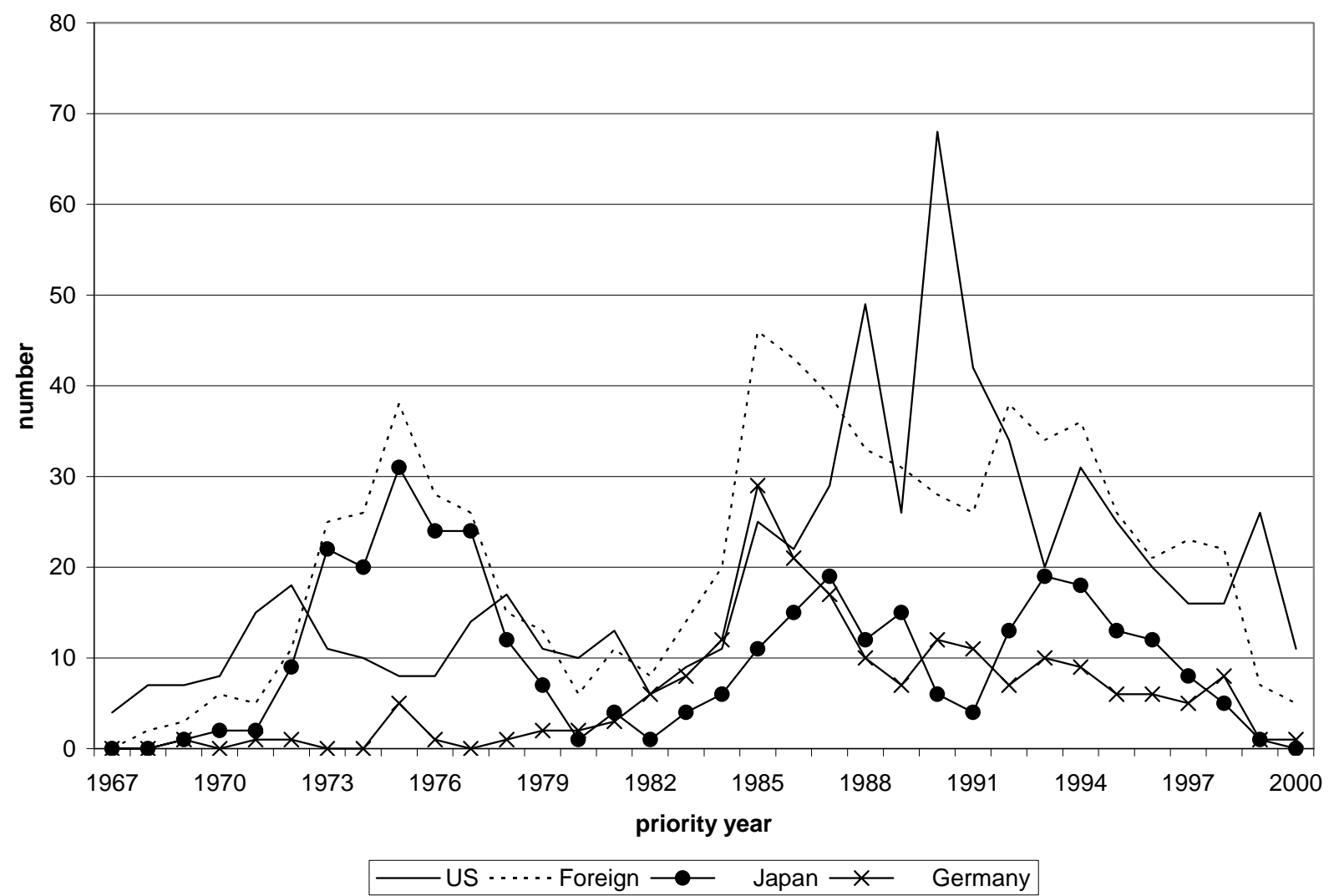

The figure shows patents granted in the United States for post-combustion treatment of $\mathrm{NO}_{\mathrm{X}}$ emissions. Patents are sorted by the home country of the assignee and by priority year. Note that patents from each country respond to regulations in that country, but there is little evidence of foreign patents responding to US regulatory pressures. Also, because of stronger regulations abroad, foreign inventors have as many, and often more patents, than US inventors. 


\section{Figure 4 -- $\mathrm{NO}_{\mathrm{X}}$ Post-Combustion Patents in Germany}

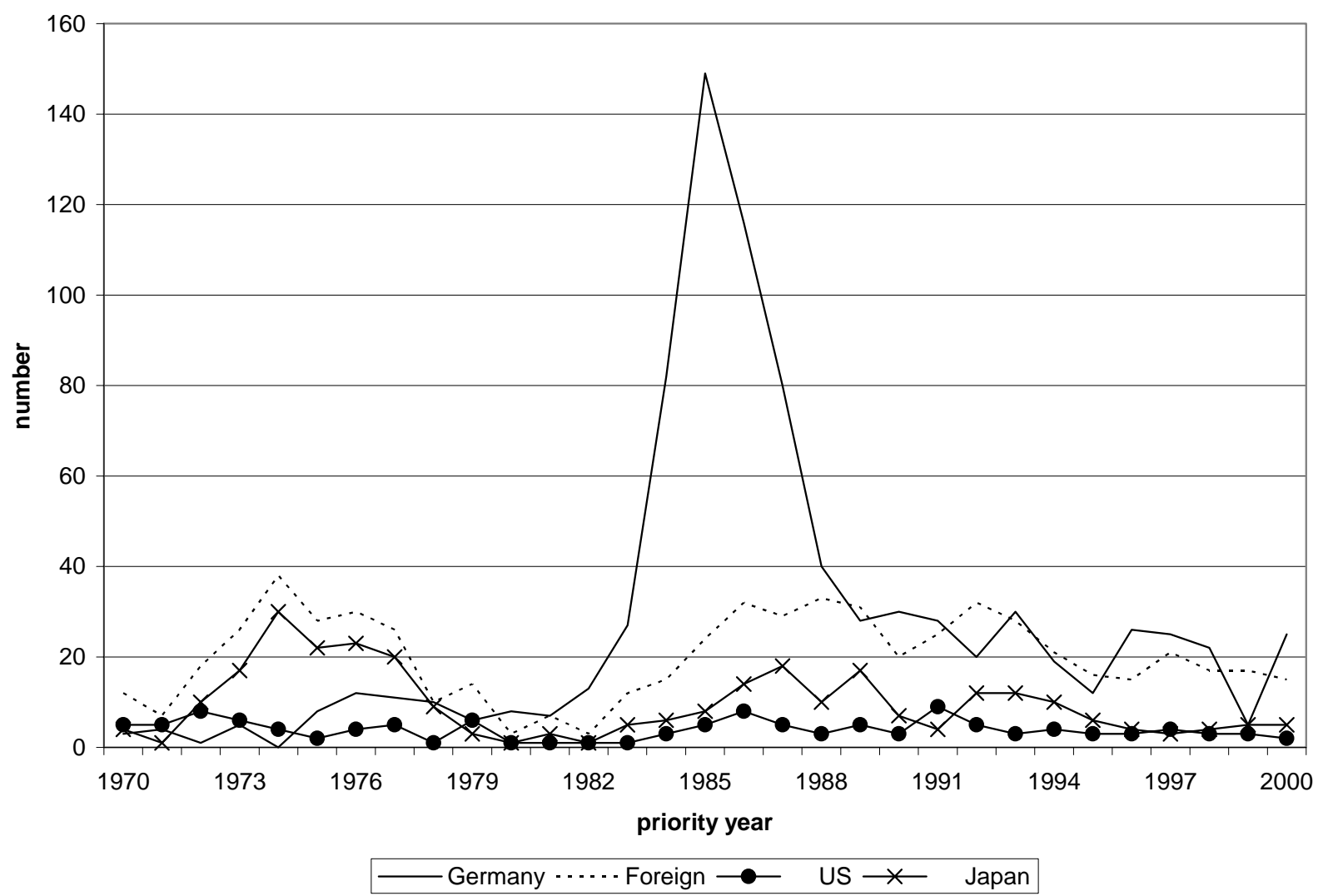

The figure shows patents granted in Germany for post-combustion treatment of $\mathrm{NO}_{\mathrm{X}}$ emissions. Patents are sorted by the home country of the assignee and by priority year. Note that German inventors respond dramatically to the passage of strict $\mathrm{NO}_{\mathrm{X}}$ emission standards in 1983, but foreign inventors do not. 


\section{Figure 5 - Pollution Control Patents in Japan}

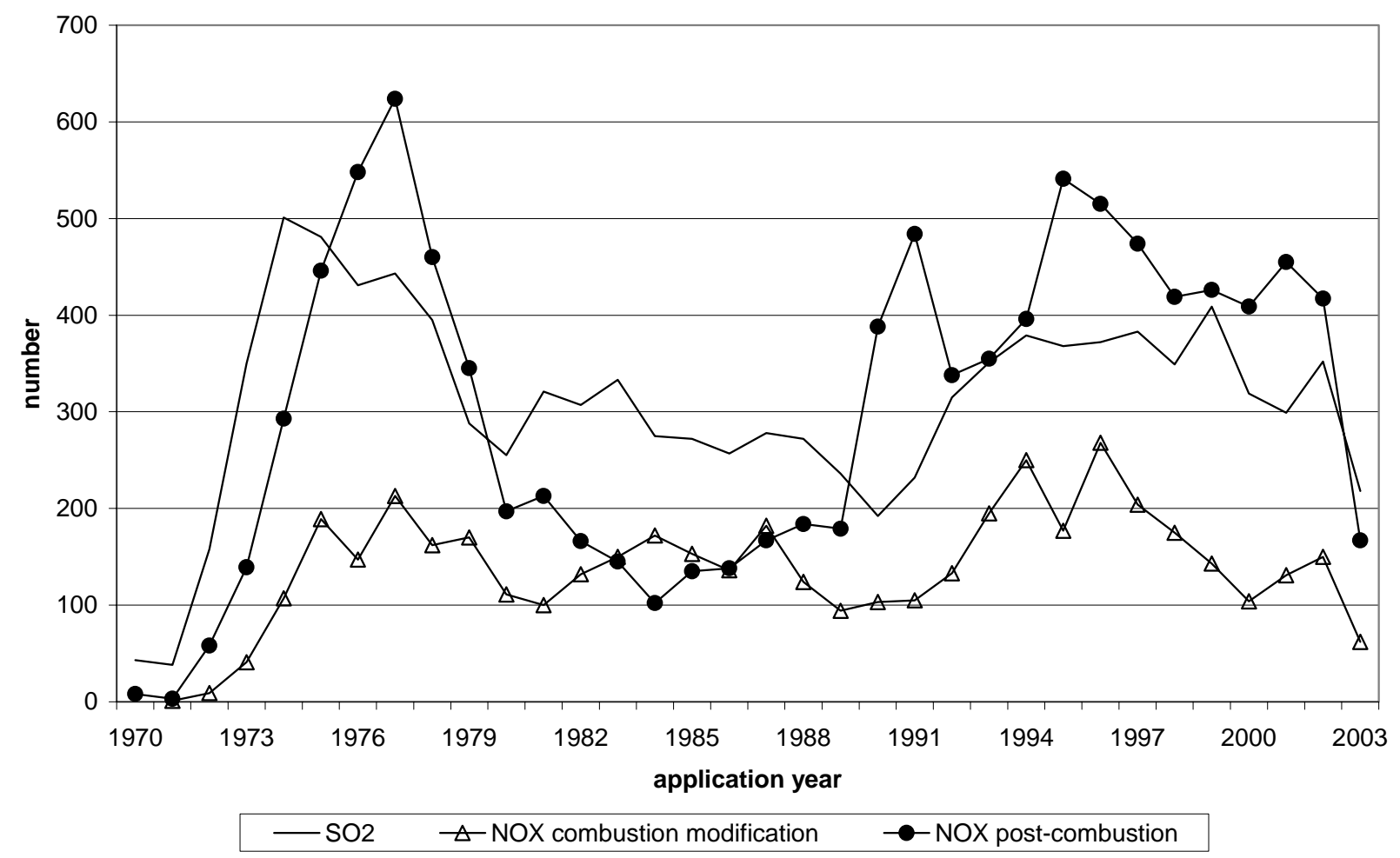

The figure shows patents granted in Japan for each pollution control technology. Unlike patents for Germany and the US, a breakdown of patents by inventor country is not available. Patents are sorted by their application year. Peak patenting activities correspond with the 1974 amendments to the Air Pollution Control Law and tighter $\mathrm{NO}_{\mathrm{X}}$ standards passed in 1987. 


\section{Figure $6-\mathrm{NO}_{\mathrm{X}}$ Combustion Modification Patents in the United States}

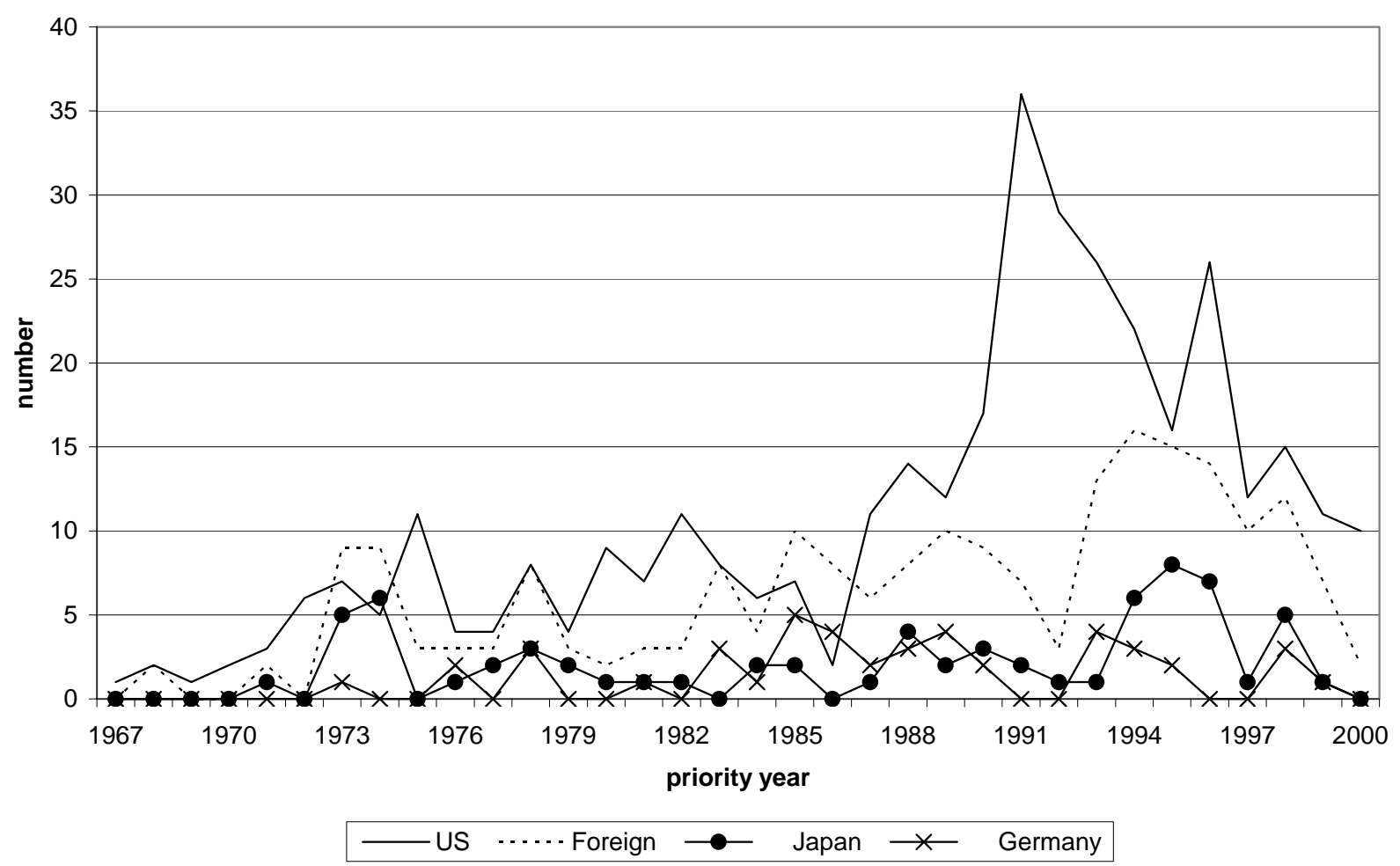

The figure shows patents granted in the United States for combustion modification techniques to control $\mathrm{NO}_{\mathrm{X}}$ emissions. Patents are sorted by the home country of the assignee and by priority year. Unlike post-combustion control techniques, US inventors are the main source of patents for combustion modification. 
Figure 7 - $\mathrm{NO}_{\mathrm{X}}$ Combustion Modification Patents in Germany

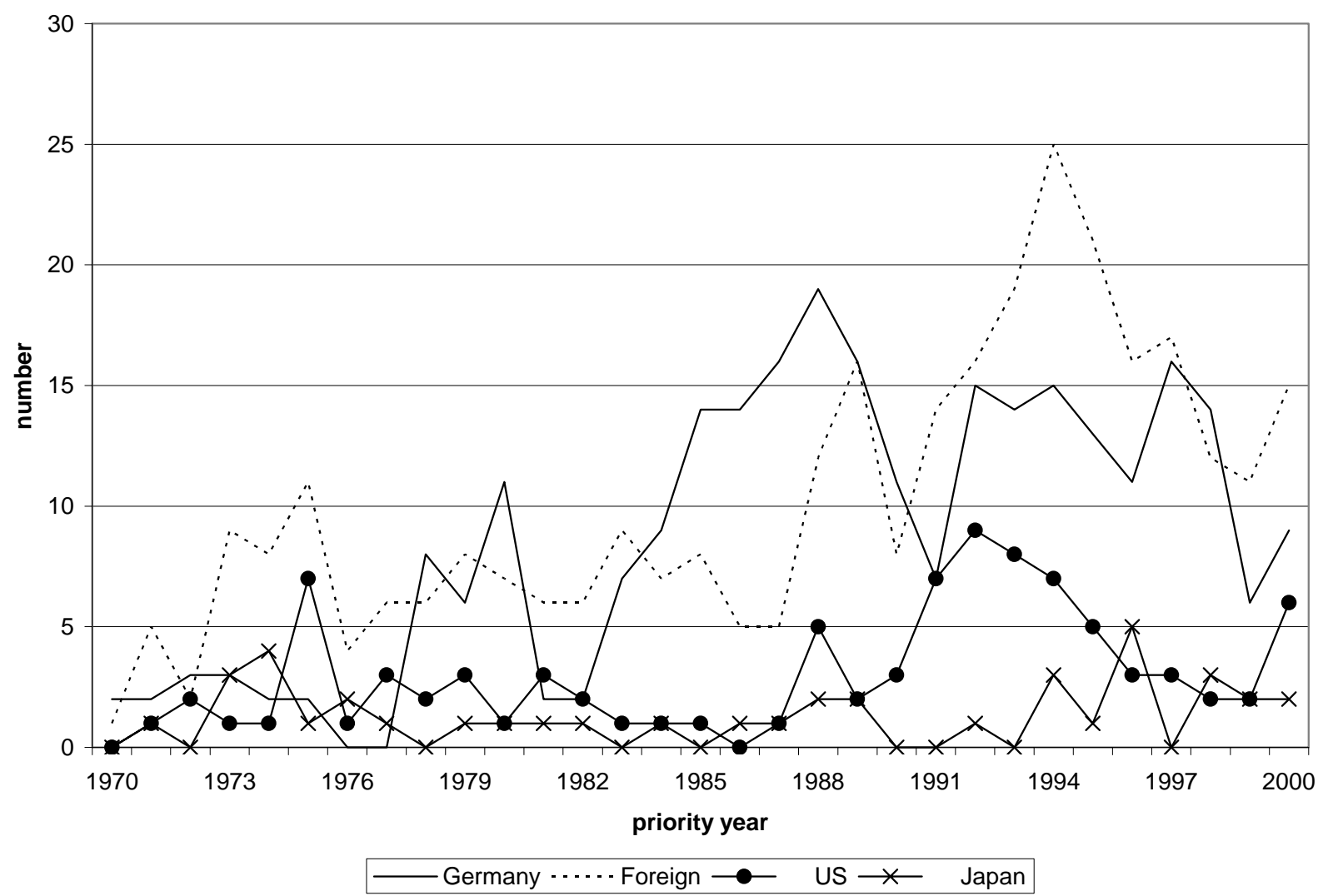

The figure shows patents granted in Germany for combustion modification techniques to control $\mathrm{NO}_{\mathrm{X}}$ emissions. Patents are sorted by the home country of the assignee and by priority year. German inventors respond to the passage of strict $\mathrm{NO}_{\mathrm{X}}$ emission standards in 1983, but not as dramatically as for post-combustion control techniques. 
Figure $8-\mathrm{SO}_{2}$ Control Patents in the United States

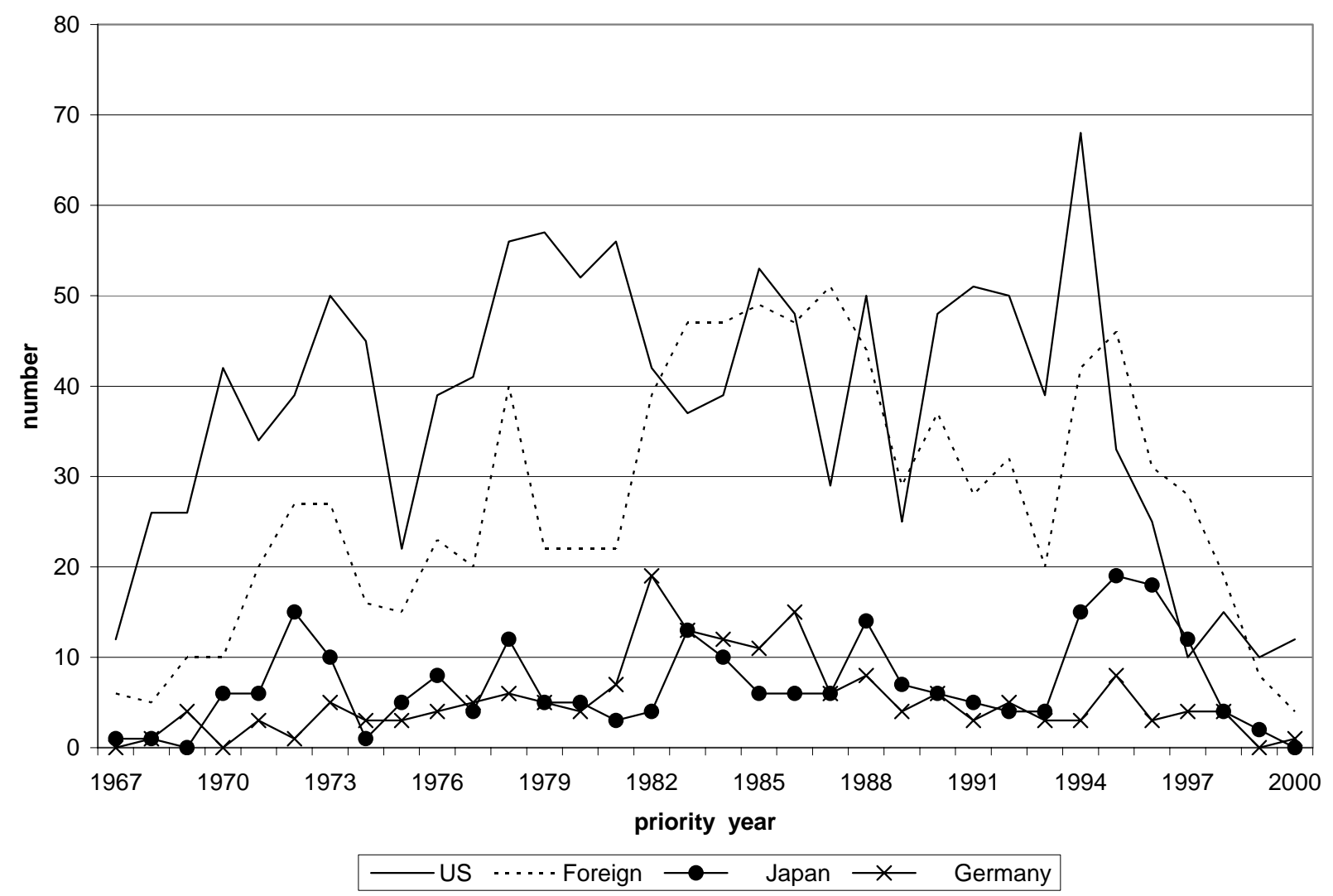

The figure shows patents granted in the United States for $\mathrm{SO}_{2}$ control techniques. Patents are sorted by the home country of the assignee and by priority year. Compared to $\mathrm{NO}_{\mathrm{X}}$ control technologies, US inventive activity is larger and more consistent, reflecting the stringent nature of $\mathrm{SO}_{2}$ regulations throughout the period. 


\section{Figure 9 - $\mathrm{SO}_{2}$ Control Patents in Germany}

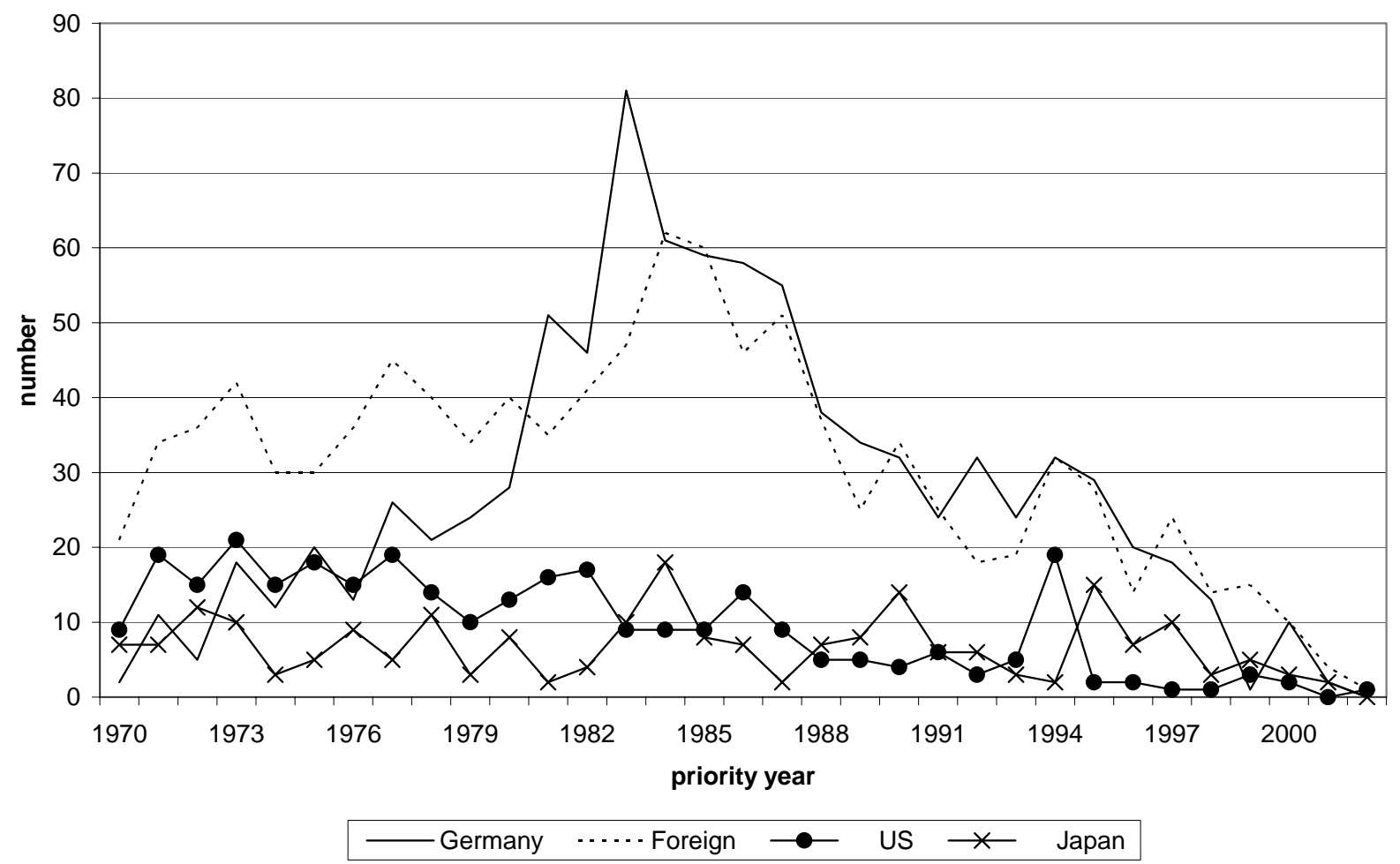

The figure shows patents granted in Germany for $\mathrm{SO}_{2}$ pollution control. Patents are sorted by the home country of the assignee and by priority year. Once again, we see that German inventors respond to the passage of strict emission standards in 1983, but foreign inventors do not. 
Table 1 - Summary of $\mathrm{NO}_{\mathrm{X}}$ Control Techniques Used at Coal-Fired Power Plants

\begin{tabular}{|c|c|c|c|c|c|c|}
\hline & US & $\%$ & Germany & $\%$ & Japan & $\%$ \\
\hline Total number of plants & 1150 & & 228 & & 87 & \\
\hline Combustion modification only & 415 & $36.1 \%$ & 68 & $29.8 \%$ & 22 & $25.3 \%$ \\
\hline Use post-combustion & 44 & $3.8 \%$ & 118 & $51.8 \%$ & 51 & $58.6 \%$ \\
\hline \multicolumn{7}{|l|}{ of these: } \\
\hline Post-combustion only & 22 & $1.9 \%$ & 27 & $11.8 \%$ & 6 & $6.9 \%$ \\
\hline Both & 22 & $1.9 \%$ & 91 & $39.9 \%$ & 45 & $51.7 \%$ \\
\hline
\end{tabular}

The table shows the total number of coal-fired power plants reported in the CoalPower4 database as of 2000, as well as the number of plants using each type of $\mathrm{NO}_{\mathrm{X}}$ control technique. For those plants using post-combustion techniques, the last rows indicate whether they use post-control techniques alone or in tandem with combustion modification. 
Table 2 - Top Equipment Suppliers for Selected Technologies

\begin{tabular}{lcc}
\hline \hline A. NOX post-combustion equipment for US plants & Number & $\begin{array}{c}\text { Percent of } \\
\text { total supplied }\end{array}$ \\
Babcock and Wilcox & 17 & $20.5 \%$ \\
Black \& Veatch/Steag & 10 & $12.0 \%$ \\
Foster Wheeler Energy Corporation & 8 & $9.6 \%$ \\
Sargent \& Lundy & 7 & $8.4 \%$ \\
ABB Combustion Engineering & 7 & $8.4 \%$ \\
Hamon Research-Cottrell, Inc. & 6 & $7.2 \%$ \\
\hline & & \\
B. SO2 equipment for German plants & & \\
& Number & Percent of \\
& supplied & total supplied \\
\cline { 2 - 3 } Lentjes Bischoff GmbH & 34 & $18.6 \%$ \\
Noell-KRC Energie und Umwelttechnik GmbH & 34 & $18.6 \%$ \\
Deutsche Babcock Anlagen GmbH & 29 & $15.8 \%$ \\
L. und C. Steinmueller GmbH & 19 & $10.4 \%$ \\
Thyssen Still Otto Anlagentechnik GmbH & 16 & $8.7 \%$ \\
Saarberg Hoelter Lurgi GmbH & 13 & $7.1 \%$ \\
\hline \hline
\end{tabular}

The table shows the top equipment suppliers for selected pollution control technologies in the US and Germany. In both cases, domestic suppliers dominate, even though early development of each technology occurred overseas. 
Table 3 - Patent Classes Used for Potentially Cited Patents

\begin{tabular}{lc}
\hline \hline & \\
Classification & $\begin{array}{c}\text { of all } \\
\text { citations }\end{array}$ \\
\hline NOX Post-Combustion & 47.8 \\
423: Chemistry of inorganic compounds & 13.2 \\
502: Catalyst, solid sorbent, or support therefor: product or process of making & 6.1 \\
422: Chemical apparatus and process disinfecting, deodorizing, preserving, or sterilizing & 43.9 \\
\hline NOX Combustion Modification & 16.6 \\
431: Combustion & 13.4 \\
110: Furnaces & \\
60: Power Plants & 31.9 \\
\hline SO2 Control & 12.0 \\
423: Chemistry of inorganic compounds & 11.2 \\
110: Furnaces & 6.7 \\
122: Liquid heaters and vaporizers & 5.8 \\
422: Chemical apparatus and process disinfecting, deodorizing, preserving, or sterilizing \\
95: Gas Separation: Processes & \\
\hline Other Pollution Control & 18.7 \\
423: Chemistry of inorganic compounds & 9.2 \\
422: Chemical apparatus and process disinfecting, deodorizing, preserving, or sterilizing & 8.7 \\
210: Liquid purification or separation & 7.1 \\
95: Gas Separation: Processes & 7.1 \\
502: Catalyst, solid sorbent, or support therefor: product or process of making & 5.5 \\
96: Gas Separation: Apparatus & \\
\hline \hline
\end{tabular}

The table shows the US patent classifications used to create the pool of potentially cited patents for the regressions in section V. These classes represent between 56 and 73 percent of all cited patents. 
Table 4 - Citation Regression Results

\begin{tabular}{|c|c|c|c|}
\hline Parameter & Estimate & $\begin{array}{c}\text { Standard } \\
\text { Error }\end{array}$ & $\begin{array}{c}\text { T-ratio }\left(\mathrm{H}_{0}\right. \\
\beta=1)\end{array}$ \\
\hline \multicolumn{4}{|l|}{ Technology Dummies } \\
\hline NOX pre combustion & 1.762 & 0.027 & 28.12 \\
\hline NOX post combustion & 0.906 & 0.017 & -5.45 \\
\hline Sulfur dioxide & 1.000 & NA & NA \\
\hline Other pollution control & 0.458 & 0.011 & -48.83 \\
\hline \multicolumn{4}{|l|}{ Citing Year } \\
\hline 1974-1977 & 1.000 & NA & NA \\
\hline 1978-1981 & 0.920 & 0.038 & -2.12 \\
\hline 1982-1985 & 1.079 & 0.052 & 1.52 \\
\hline 1986-1989 & 1.306 & 0.074 & 4.13 \\
\hline 1990-1993 & 1.519 & 0.100 & 5.19 \\
\hline 1994-1997 & 1.418 & 0.108 & 3.89 \\
\hline $1998-2001$ & 1.417 & 0.123 & 3.40 \\
\hline \multicolumn{4}{|l|}{ Cited Year } \\
\hline 1963-1970 & 1.000 & NA & NA \\
\hline 1971-1975 & 2.077 & 0.145 & 7.46 \\
\hline 1976-1980 & 2.347 & 0.181 & 7.44 \\
\hline 1981-1985 & 1.965 & 0.171 & 5.65 \\
\hline 1986-1990 & 2.071 & 0.201 & 5.32 \\
\hline 1991-1995 & 2.062 & 0.222 & 4.78 \\
\hline $1996-2001$ & 2.066 & 0.251 & 4.24 \\
\hline \multicolumn{4}{|l|}{ Citing/Cited Country Pairs } \\
\hline US citing US & 1.000 & NA & NA \\
\hline US citing Japan & 0.589 & 0.017 & -24.05 \\
\hline US citing Germany & 0.638 & 0.021 & -17.64 \\
\hline US citing Other nations & 0.568 & 0.016 & -27.51 \\
\hline Japan citing US & 0.387 & 0.016 & -39.53 \\
\hline Japan citing Japan & 1.070 & 0.035 & 2.02 \\
\hline Japan citing Germany & 0.397 & 0.037 & -16.35 \\
\hline Japan citing Other nations & 0.337 & 0.031 & -21.53 \\
\hline Germany citing US & 0.319 & 0.018 & -38.07 \\
\hline Germany citing Japan & 0.611 & 0.033 & -11.82 \\
\hline Germany citing Germany & 0.923 & 0.046 & -1.69 \\
\hline Germany citing Other Nations & 0.356 & 0.036 & -17.99 \\
\hline Other nations citing US & 0.480 & 0.014 & -38.55 \\
\hline Other nations citing Japan & 0.339 & 0.025 & -26.56 \\
\hline Other nations citing Germany & 0.495 & 0.031 & -16.38 \\
\hline Other nations citing Other nations & 0.735 & 0.025 & -10.72 \\
\hline \multicolumn{4}{|c|}{ Citing pattern differences for NOX post-combustion patents } \\
\hline US citing US & 0.000 & NA & NA \\
\hline US citing Japan & 0.610 & 0.059 & $10.36^{*}$ \\
\hline US citing Germany & 0.057 & 0.055 & $1.03^{*}$ \\
\hline US citing Other nations & -0.401 & 0.043 & $-9.43^{*}$ \\
\hline Decay & 0.243 & 0.004 & $63.74^{\star}$ \\
\hline Diffusion & 0.00011 & 0.00001 & $14.07^{*}$ \\
\hline
\end{tabular}


Table 5 - Alternative Citation Regression Specifications

\begin{tabular}{|c|c|c|c|c|}
\hline & $(1)$ & $(2)$ & (3) & (4) \\
\hline \multicolumn{5}{|c|}{ Citing pattern differences for NOX post-combustion patents } \\
\hline \multirow[t]{2}{*}{ US citing US } & 0 & & 0 & \\
\hline & NA & & NA & \\
\hline \multirow[t]{2}{*}{ US citing Japan } & 0.610 & & 0.716 & \\
\hline & $(10.36)$ & & $(9.64)$ & \\
\hline \multirow[t]{2}{*}{ US citing Germany } & 0.057 & & 0.094 & \\
\hline & $(1.03)$ & & $(1.41)$ & \\
\hline \multirow[t]{2}{*}{ US citing Other nations } & -0.401 & & -0.342 & \\
\hline & $(-9.43)$ & & $(-6.87)$ & \\
\hline \multicolumn{5}{|c|}{ Citing pattern differences for pre-1990 NOX post-combustion patents } \\
\hline \multirow[t]{2}{*}{ US citing US } & & 0 & & 0 \\
\hline & & NA & & NA \\
\hline \multirow[t]{2}{*}{ US citing Japan } & & 2.244 & & 2.517 \\
\hline & & $(17.92)$ & & $(15.86)$ \\
\hline \multirow[t]{2}{*}{ US citing Germany } & & -0.121 & & -0.057 \\
\hline & & $(-1.48)$ & & $(-0.62)$ \\
\hline \multirow[t]{2}{*}{ US citing Other nations } & & -0.358 & & -0.274 \\
\hline & & $(-4.55)$ & & $(-3.03)$ \\
\hline \multicolumn{5}{|c|}{ Citing pattern differences for post-1990 NOX post-combustion patents } \\
\hline \multirow[t]{2}{*}{ US citing US } & & 0 & & 0 \\
\hline & & NA & & NA \\
\hline \multirow[t]{2}{*}{ US citing Japan } & & -0.669 & & 0.679 \\
\hline & & $(-42.91)$ & & $(7.46)$ \\
\hline \multirow[t]{2}{*}{ US citing Germany } & & 0.294 & & 0.161 \\
\hline & & $(2.30)$ & & $(2.16)$ \\
\hline \multirow[t]{2}{*}{ US citing Other nations } & & -0.093 & & 0.286 \\
\hline & & $(-0.72)$ & & (4.18) \\
\hline
\end{tabular}

Table continued on next page 


\section{Table 5 - Alternative Citation Regression Specifications (continued)}

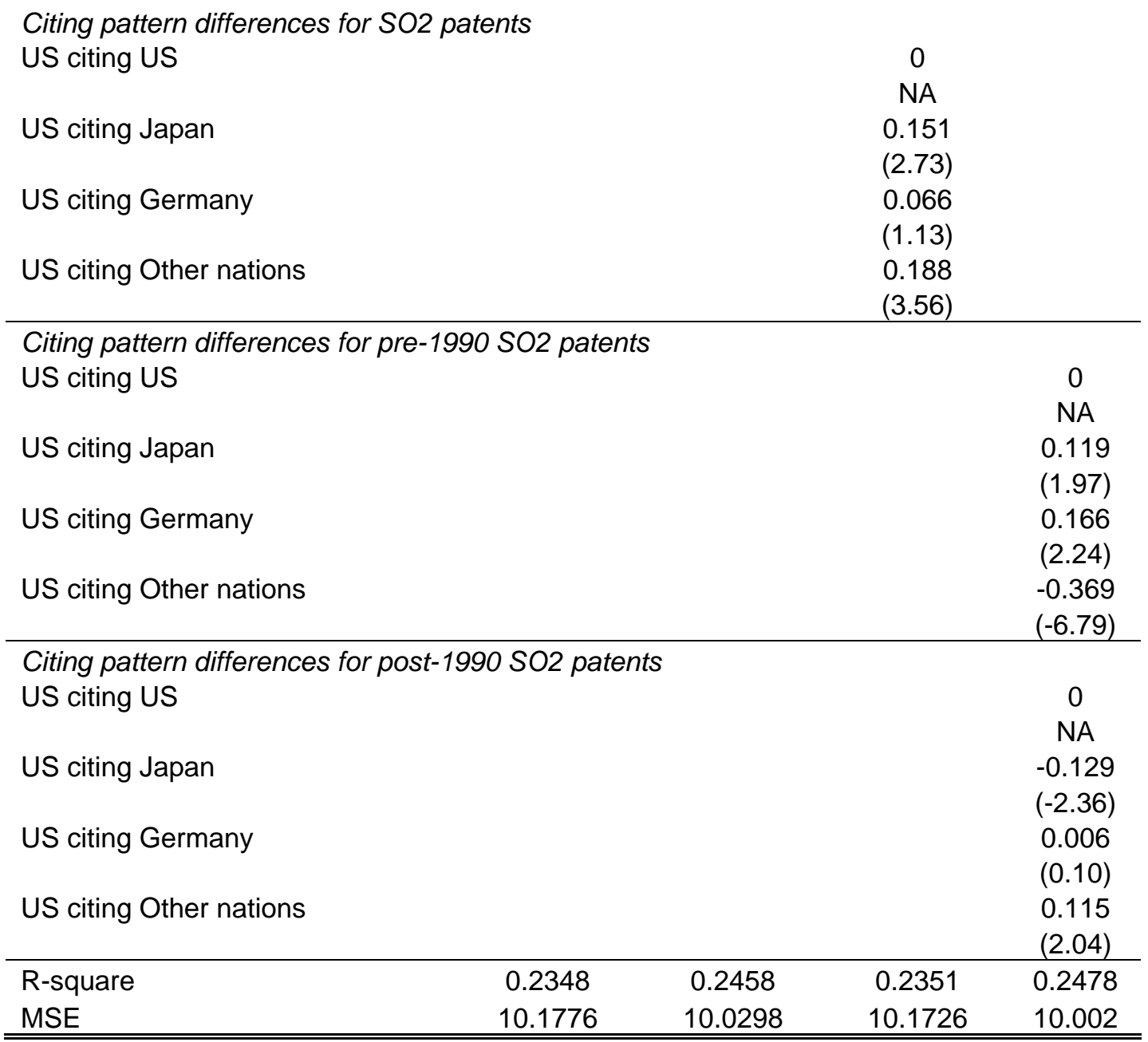

T-statistics in parenthesis

The table presents results of differing citation patterns for alternative specifications of the citation regression. Column (1) repeats the results presented in table 4 for the $\mathrm{NO}_{\mathrm{X}}$ postcombustion citation pattern dummy. Column (2) presents results of a regression distinguishing between cited $\mathrm{NO}_{\mathrm{X}}$ post-combustion patents granted before and after 1990. Columns (3) and (4) repeat this analysis, including dummy variables for both $\mathrm{NO}_{\mathrm{X}}$ post-combustion techniques and $\mathrm{SO}_{2}$ techniques. Note that the patterns found for $\mathrm{NO}_{\mathrm{X}}$ post-combustion techniques are not found for $\mathrm{SO}_{2}$ technologies, nor does the inclusion of $\mathrm{SO}_{2}$ technologies change the pattern of results for $\mathrm{NO}_{\mathrm{X}}$ post-combustion techniques. 


\section{Data Appendix A - Creation of the Patent Data Set}

When patents are granted, they are given technology classifications and subclassifications by various patent offices. These classifications can be used to identify all patents for each of the technologies described in section IV. For US and German patents, relevant patents were identified using the European Classification System (ECLA). ECLA classifications are assigned to patent examiners at the European Patent Office (EPO). The EPO provides a searchable on-line database, esp@cenet, that includes ECLA classifications for all German patents and all US patents granted since $1920 .^{27}$ This classification scheme is based upon the often-used International Patent Classification system (IPC), but includes classifications at a greater level of detail. This additional detail allows for separate identification of technologies based on the pollutants they control. For example, IPC classification B01D 53/86 includes catalytic processes for pollution control. ECLA class B01D 53/86F2 specifies catalytic processes for reduction of $\mathrm{NO}_{\mathrm{X}}$, and B01D 53/86B4 specifies catalytic processes for reduction of $\mathrm{SO}_{2}$. Moreover, as new classifications are added, the EPO updates the ECLA of older patents in its database. This is important, as classifications distinguishing pollution control techniques for specific pollutants were not added until recently. Using the EPO’s on-line database, a list of all patent numbers in relevant technology classes was downloaded for the US, Germany, and the EPO. ${ }^{28}$

However, the EPO database does not include complete updates of the ECLA for Japanese patents. Thus, Japanese patents were obtained from the Intellectual Property Digital Library on

\footnotetext{
${ }^{27}$ The database can be found at http://ep.espacenet.com/search97cgi/s97is.dll?Action=FormGen\&Template=ep/en/ home.hts

${ }^{28}$ Beginning in 1978, an inventor desiring protection in Europe could file a single patent application through the EPO. The applicant designates as many of the $18 \mathrm{EPO}$ member-states for protection as desired. The application is examined by the EPO. If granted, the patent is transferred to the individual national patent offices designated for protection. Typically, a patent applicant first files for protection in their home country, and then applies to offices abroad, such as the EPO. The esp@cenet database returns patent numbers for patents with German priority that were also filed through the EPO, but does not return the German patent numbers for patents with foreign priority that were filed through EPO and designated Germany for protection. Thus, foreign patent counts in Germany are augmented by including EPO patents from non-German inventors that designate Germany for protection.
} 
the Japan Patent Office (JPO) web site. ${ }^{29}$ The JPO does not use the ECLA. However, it uses its own system, the F-term, which, like the ECLA, provides greater detail than the IPC. F-terms consist of a 5-digit theme code, a 2-digit viewpoint symbol, and a 2-digit number. For example, consider technologies classified as 4D002 AA12. The 5-digit theme code 4D002 pertains to “processing of waste gases." The two letter viewpoint symbol AA pertains to "compounds to be processed.” Finally, the 2-digit number specifies that $\mathrm{NO}_{\mathrm{X}}$ is the component processed.

The first step in assembling the patent data used in this paper was to identify relevant ECLA classifications. Information on appropriate technologies was obtained from several sources. Much of this information is summarized through documents available from the International Energy Agency’s (IEA) Clean Coal Research Centre, and is available on-line at htpp://www.iea-coal.org.uk. Keyword searches were used to identify potentially relevant patents. Individual documents were viewed to determine which were, in fact, patents pertaining to pollution control. A tally of the ECLA classifications of these patents was made, enabling us to identify classifications that occurred frequently in the data. Then, searches of these ECLAs were done both separately and in combination with relevant keywords to identify classifications for which the majority of patents did pertain to pollution control. This last step was particularly important for combustion modification patents, as many patents in potential combustion classifications pertain to other aspects of combustion (e.g. for improving horsepower). Once the relevant ECLA classes were found, they were matched to corresponding F-term classes in the Japanese system, using both a reading of the various definitions and searches of the Intellectual Property Digital Library of the JPO using the IPC class most closely corresponding to the ECLA codes.

${ }^{29}$ This database can be found at http://www.ipdl.jpo.go.jp/homepg_e.ipdl. 
After establishing the patent classifications to use in this research, the next research step was to obtain a list of all patents from the US, Japan, Germany, and the EPO in these classifications. Patent numbers from all but Japan were obtained from esp@cenet, and the Japanese data came from the Intellectual Property Digital Library of the JPO. Because of differences in patent laws in each country, slightly different data are available from each site. US data is only available for granted patents, as patent applications were not published by the US Patent Office until 2001. In contrast, both successful and unsuccessful patent applications are available for Germany and the EPO. Finally, the Japanese database contains information on all patent applications since 1971. Using application data, rather than granted patents, is more reliable for Japan, as the patent examination process in Japan often takes six or more years, compared to 2-3 years in the United States.

Both of these sources provide lists of patents, but do not allow the user to download large quantities of descriptive data about the patents. Thus, we augmented the patent numbers with descriptive information downloaded from the Delphion on-line database. ${ }^{30}$ This database, available only by subscription, allows the user to download multiple patent records in machinereadable formats. Descriptive data available include the priority, application and issue dates for each patent, the home country of the inventor, and data on patent families. Unfortunately, updated ECLA classifications are not available from Delphion. Thus, we downloaded patents from Delphion that fell in related IPC classifications, and merged these data with the lists of patent numbers to restrict the analysis to those falling in the relevant ECLA classes. Also, the Delphion database does not include detailed descriptive data for Japanese patents. Fortunately, the application year of each patent is available from the JPO website. However, the priority date of these patents is unavailable.

\footnotetext{
${ }^{30}$ Available at http://www.delphion.com.
} 


\title{
Appendix B - Patent Classifications Used for Each Control Technology
}

\author{
European Classifications for Pollution Control Patents
}

\section{Nitrogen Dioxide pollution control}

Combustion Modification

F23C 6/04B MECHANICAL ENGINEERING; LIGHTING; HEATING; WEAPONS; BLASTING ENGINES OR PUMPS/COMBUSTION APPARATUS; COMBUSTION PROCESSES/COMBUSTION APPARATUS USING FLUENT FUEL/Combustion apparatus characterised by the combination of two or more combustion chambers/in series connection/[N: with staged combustion in a single enclosure]

F23C 6/04B1 MECHANICAL ENGINEERING; LIGHTING; HEATING; WEAPONS; BLASTING ENGINES OR PUMPS/COMBUSTION APPARATUS; COMBUSTION PROCESSES/COMBUSTION APPARATUS USING FLUENT FUEL/Combustion apparatus characterised by the combination of two or more combustion chambers/in series connection/[N: with staged combustion in a single enclosure]/ [N: with fuel supply in stages]

F23C 9 MECHANICAL ENGINEERING; LIGHTING; HEATING; WEAPONS; BLASTING ENGINES OR PUMPS/COMBUSTION APPARATUS; COMBUSTION PROCESSES/COMBUSTION APPARATUS USING FLUENT FUEL/Combustion apparatus with arrangements for recycling or recirculating combustion products or flue gases

Post-Combustion B01D 53/56 PERFORMING OPERATIONS; TRANSPORTING/ PHYSICAL OR CHEMICAL PROCESSES OR APPARATUS IN GENERAL/ SEPARATION/ Separation of gases or vapours; Recovering vapours of volatile solvents from gases; Chemical or biological purification of waste gases, e.g. engine exhaust gases, smoke, fumes, flue gases, aerosols/Chemical or biological purification of waste gases/Removing components of defined structure/Nitrogen compounds/Nitrogen oxides

B01D 53/56D PERFORMING OPERATIONS; TRANSPORTING/ PHYSICAL OR CHEMICAL PROCESSES OR APPARATUS IN GENERAL/ SEPARATION/ Separation of gases or vapours; Recovering vapours of volatile solvents from gases; Chemical or biological purification of waste gases, e.g. engine exhaust gases, smoke, fumes, flue gases, aerosols/Chemical or biological purification of waste gases/Removing components of defined structure/Nitrogen compounds/Nitrogen oxides/[N: by treating the gases with solids] 
B01D 53/60

B01D 53/86F2

B01D 53/86F2C

B01D 53/86F2D

B01D 53/86G
PERFORMING OPERATIONS; TRANSPORTING/ PHYSICAL OR CHEMICAL PROCESSES OR APPARATUS IN GENERAL/ SEPARATION/ Separation of gases or vapours; Recovering vapours of volatile solvents from gases; Chemical or biological purification of waste gases, e.g. engine exhaust gases, smoke, fumes, flue gases, aerosols/Chemical or biological purification of waste gases/Removing components of defined structure/Simultaneously removing sulfur oxides and nitrogen oxides PERFORMING OPERATIONS; TRANSPORTING/ PHYSICAL OR CHEMICAL PROCESSES OR APPARATUS IN GENERAL/ SEPARATION/ Separation of gases or vapours; Recovering vapours of volatile solvents from gases; Chemical or biological purification of waste gases, e.g. engine exhaust gases, smoke, fumes, flue gases, aerosols/Chemical or biological purification of waste gases/General processes for purification of waste gases; Apparatus or devices specially adapted therefore/Catalytic processes/ N: Removing nitrogen compounds]/[N: Nitrogen oxides]/

PERFORMING OPERATIONS; TRANSPORTING/ PHYSICAL OR CHEMICAL PROCESSES OR APPARATUS IN GENERAL/ SEPARATION/ Separation of gases or vapours; Recovering vapours of volatile solvents from gases; Chemical or biological purification of waste gases, e.g. engine exhaust gases, smoke, fumes, flue gases, aerosols/Chemical or biological purification of waste gases/General processes for purification of waste gases; Apparatus or devices specially adapted therefore/Catalytic processes/ N: Removing nitrogen compounds]/[N: Nitrogen oxides]/[N: Processes characterised by a specific catalyst]

PERFORMING OPERATIONS; TRANSPORTING/ PHYSICAL OR CHEMICAL PROCESSES OR APPARATUS IN GENERAL/ SEPARATION/ Separation of gases or vapours; Recovering vapours of volatile solvents from gases; Chemical or biological purification of waste gases, e.g. engine exhaust gases, smoke, fumes, flue gases, aerosols/Chemical or biological purification of waste gases/General processes for purification of waste gases; Apparatus or devices specially adapted therefore/Catalytic processes/ N: Removing nitrogen compounds]/[N: Nitrogen oxides [N: Processes characterised by a specific device]

PERFORMING OPERATIONS; TRANSPORTING/ PHYSICAL OR CHEMICAL PROCESSES OR APPARATUS IN GENERAL/ SEPARATION/ Separation of gases or vapours; Recovering vapours of volatile solvents from gases; Chemical or biological purification of waste gases, e.g. engine exhaust gases, smoke, fumes, flue gases, aerosols/Chemical or biological purification of waste gases/General processes for purification of waste gases; Apparatus or devices specially adapted therefore/Catalytic processes/ [N: Simultaneously removing sulfur oxides and nitrogen oxides] 
B01J 29/06D2E PERFORMING OPERATIONS; TRANSPORTING/ PHYSICAL OR CHEMICAL PROCESSES OR APPARATUS IN GENERAL/ CHEMICAL OR PHYSICAL PROCESSES, e.g. CATALYSIS, COLLOID CHEMISTRY; THEIR RELEVANT APPARATUS/

Catalysts comprising molecular sieves/ having base-exchange properties, e.g. crystalline zeolites/ Crystalline aluminosilicate zeolites; Isomorphous compounds thereof/ [N: containing metallic elements added to the zeolite]/ [N: containing iron group metals, noble metals or copper]/ [N: Iron group metals or copper]

\section{Sulfur Dioxide pollution control}

B01D 53/14H8

B01D 53/50

B01D 53/86B4

F23C 10
PERFORMING OPERATIONS; TRANSPORTING/ PHYSICAL OR CHEMICAL PROCESSES OR APPARATUS IN GENERAL/ SEPARATION/ Separation of gases or vapours; Recovering vapours of volatile solvents from gases; Chemical or biological purification of waste gases, e.g. engine exhaust gases, smoke, fumes, flue gases, aerosols/ by absorption/ [N: Gases containing acid components]/ [N: containing only sulfur dioxide or sulfur trioxide] PERFORMING OPERATIONS; TRANSPORTING/ PHYSICAL OR CHEMICAL PROCESSES OR APPARATUS IN GENERAL/ SEPARATION/ Separation of gases or vapours; Recovering vapours of volatile solvents from gases; Chemical or biological purification of waste gases, e.g. engine exhaust gases, smoke, fumes, flue gases, aerosols/Chemical or biological purification of waste gases/Removing components of defined structure/Sulfur compounds/Sulfur oxides Includes 50B, 50B2, 50B4, 50B6, 50C, 50D

PERFORMING OPERATIONS; TRANSPORTING/ PHYSICAL OR CHEMICAL PROCESSES OR APPARATUS IN GENERAL/ SEPARATION/ Separation of gases or vapours; Recovering vapours of volatile solvents from gases; Chemical or biological purification of waste gases, e.g. engine exhaust gases, smoke, fumes, flue gases, aerosols/Chemical or biological purification of waste gases/General processes for purification of waste gases; Apparatus or devices specially adapted therefore/Catalytic processes/ [N: Removing sulfur compounds]/ [N: Sulfur oxides]

MECHANICAL ENGINEERING; LIGHTING; HEATING; WEAPONS; BLASTING ENGINES OR PUMPS/COMBUSTION APPARATUS; COMBUSTION PROCESSES/COMBUSTION APPARATUS USING FLUENT FUEL/ Fluidised bed combustion apparatus 


\section{General Pollution Control}

B01D 53/34

PERFORMING OPERATIONS; TRANSPORTING/ PHYSICAL OR CHEMICAL PROCESSES OR APPARATUS IN GENERAL/

SEPARATION/ Separation of gases or vapours; Recovering vapours of volatile solvents from gases; Chemical or biological purification of waste gases, e.g. engine exhaust gases, smoke, fumes, flue gases, aerosols/Chemical or biological purification of waste gases

B01D 53/74 PERFORMING OPERATIONS; TRANSPORTING/ PHYSICAL OR CHEMICAL PROCESSES OR APPARATUS IN GENERAL/ SEPARATION/ Separation of gases or vapours; Recovering vapours of volatile solvents from gases; Chemical or biological purification of waste gases, e.g. engine exhaust gases, smoke, fumes, flue gases, aerosols/Chemical or biological purification of waste gases/General processes for purification of waste gases; Apparatus or devices specially adapted therefore

B01D 53/86 PERFORMING OPERATIONS; TRANSPORTING/ PHYSICAL OR CHEMICAL PROCESSES OR APPARATUS IN GENERAL/ SEPARATION/ Separation of gases or vapours; Recovering vapours of volatile solvents from gases; Chemical or biological purification of waste gases, e.g. engine exhaust gases, smoke, fumes, flue gases, aerosols/Chemical or biological purification of waste gases/General processes for purification of waste gases; Apparatus or devices specially adapted therefore/Catalytic processes 
Japanese F-terms for Pollution Control Technologies

\section{Nitrogen Dioxide pollution control}

Combustion Modification

3K091 AA01 Combustion of fluid fuel/Purpose of improvement/Control of nitrous oxides (NOx)

3K065 TA01 Other non-classified combustion/Purpose and effects of improvements/Control of nitrous oxides $\left(\mathrm{NO}_{\mathrm{X}}\right)$

3K065 QA01 Other non-classified combustion/Pollution prevention (i.e., purposes and means)/Low nitrous oxides ( $\left.\mathrm{NO}_{\mathrm{X}}\right)$

3K065 QA02 Other non-classified combustion/Pollution prevention (i.e., purposes and means)/ Low nitrous oxides $\left(\mathrm{NO}_{\mathrm{X}}\right)$ /Low nitrous oxides $\left(\mathrm{NO}_{\mathrm{X}}\right)$ by divided flames

3K065 QA03 Other non-classified combustion/Pollution prevention (i.e., purposes and means)/ Low nitrous oxides $\left(\mathrm{NO}_{\mathrm{X}}\right) /$ Low nitrous oxides $\left(\mathrm{NO}_{\mathrm{X}}\right)$ by thick and thin fuel combustion

3K065 QA04 Other non-classified combustion/Pollution prevention (i.e., purposes and means)/ Low nitrous oxides $\left(\mathrm{NO}_{\mathrm{X}}\right)$ /Low nitrous oxides $\left(\mathrm{NO}_{\mathrm{X}}\right)$ by multi-stage combustion

3K064 AA01 Fluidized-bed combustion and resonant combustion/Purpose and effect of improvements/Control or suppression of nitrous oxides $\left(\mathrm{NO}_{\mathrm{X}}\right)$

F23C 11/02,301 Other combustion apparatus using fluent fuel/with fluidised bed/ suppressing generation of $\mathrm{SO}_{\mathrm{X}}$

Post-Combustion

4D002 AA12 Processing of waste gases/Components to be processed/Nitrogen oxides (NOx)

4G069 CA13 Catalysts/Reactions used that are associated with Environmental Protection/Target substances/Nitrous oxides $\left(\mathrm{NO}_{\mathrm{X}}\right)$ 


\section{Sulfur Dioxide pollution control}

4D002 AA02 Processing of waste gases/Components to be processed/Sulfur oxide $\left(\mathrm{SO}_{\mathrm{X}}\right)$

3K091 AA02 Combustion of fluid fuel/Purpose of improvement/Control of sulfur oxides (SOx)

3K091 FB09 Combustion of fluid fuel/Air supply and fuel supply for afterburning/Forms of combustion chambers/Supply of desulfurization agents

3K065 TA02 Other non-classified combustion/Purpose and effects of improvements/Control of sulfur oxides $\left(\mathrm{SO}_{\mathrm{X}}\right)$

3K065 QA06 Other non-classified combustion/Pollution prevention (i.e., purposes and means)/Low sulfur oxides ( $\mathrm{SO}_{\mathrm{X}}$ )

3K065 QA07 Other non-classified combustion/Pollution prevention (i.e., purposes and means)/ Low sulfur oxides $\left(\mathrm{SO}_{\mathrm{X}}\right)$ /Low sulfur oxides $\left(\mathrm{SO}_{\mathrm{X}}\right)$ by desulfurization agents

3K064 AA02 Fluidized-bed combustion and resonant combustion/Purpose and effect of improvements/Control or suppression of sulfur oxides $\left(\mathrm{SO}_{\mathrm{X}}\right)$

3K065 AA11 Other non-classified combustion/Furnace shapes/Fluidized bed furnaces

F23C 11/02* Combustion apparatus; combustion processes/Combustion apparatus using fluent fuel/Other combustion apparatus using fluent fuel/with fluidised bed

F23C 11/02,303* Combustion apparatus; combustion processes/Combustion apparatus using fluent fuel Other combustion apparatus using fluent fuel/with fluidised bed/ suppressing generation of $\mathrm{SO}_{\mathrm{X}}$ (only desulfurisation in the furnace. F23C11/00, 307 takes precedence)

F23C11/00, 307* Combustion apparatus; combustion processes/Combustion apparatus using fluent fuel Other combustion apparatus using fluent fuel/suppressing generation of SOx (desulfurisation in the furnace)

* - These IPC classes are included to capture general fluidized bed combustion patents. Fluidized bed combustion has its own five digit theme code (3K064). These cannot be downloaded separately from the Japanese patent database, as the remainder of the F-term is needed for downloading. However, the corresponding IPC classes can be downloaded, and are included in the data used in the paper. 